\title{
Assessing the potential hydrological impact of the Gibe III Dam on Lake Turkana water level using multi-source satellite data
}

\author{
N. M. Velpuri ${ }^{1, *}$ and G. B. Senay ${ }^{1,2}$ \\ ${ }^{1}$ GISc Center of Excellence, South Dakota State University, Brookings, SD, USA \\ ${ }^{2}$ USGS Earth Resources Observation and Science (EROS) Center, Sioux Falls, SD, USA \\ *now at: ASRC Research and Technology Solutions, Contractor to US Geological Survey (USGS) \\ Earth Resources Observation and Science (EROS) Center, Sioux Falls, SD, USA
}

Correspondence to: G. B. Senay (senay@usgs.gov)

Received: 4 February 2012 - Published in Hydrol. Earth Syst. Sci. Discuss.: 8 March 2012

Revised: 3 July 2012 - Accepted: 6 September 2012 - Published: 11 October 2012

\begin{abstract}
Lake Turkana, the largest desert lake in the world, is fed by ungauged or poorly gauged river systems. To meet the demand of electricity in the East African region, Ethiopia is currently building the Gibe III hydroelectric dam on the Omo River, which supplies more than $80 \%$ of the inflows to Lake Turkana. On completion, the Gibe III dam will be the tallest dam in Africa with a height of $241 \mathrm{~m}$. However, the nature of interactions and potential impacts of regulated inflows to Lake Turkana are not well understood due to its remote location and unavailability of reliable in situ datasets. In this study, we used $12 \mathrm{yr}$ (1998-2009) of existing multisource satellite and model-assimilated global weather data. We used a calibrated multi-source satellite data-driven water balance model for Lake Turkana that takes into account model routed runoff, lake/reservoir evapotranspiration, direct rain on lakes/reservoirs and releases from the dam to compute lake water levels. The model evaluates the impact of the Gibe III dam using three different approaches - a historical approach, a rainfall based approach, and a statistical approach to generate rainfall-runoff scenarios. All the approaches provided comparable and consistent results. Model results indicated that the hydrological impact of the Gibe III dam on Lake Turkana would vary with the magnitude and distribution of rainfall post-dam commencement. On average, the reservoir would take up to 8-10 months, after commencement, to reach a minimum operation level of $201 \mathrm{~m}$ depth of water. During the dam filling period, the lake level would drop up to 1-2 $\mathrm{m}$ (95\% confidence) compared to the lake level modeled without the dam. The lake level variability caused by regulated inflows after the dam commissioning
\end{abstract}

were found to be within the natural variability of the lake of $4.8 \mathrm{~m}$. Moreover, modeling results indicated that the hydrological impact of the Gibe III dam would depend on the initial lake level at the time of dam commencement. Areas along the Lake Turkana shoreline that are vulnerable to fluctuations in lake levels due to the Gibe III dam were also identified. This study demonstrates the effectiveness of using existing multi-source satellite data in a basic modeling framework to assess the potential hydrological impact of an upstream dam on a terminal downstream lake. The results obtained from this study could also be used to evaluate alternative damfilling scenarios and assess the potential impact of the dam on Lake Turkana under different operational strategies.

\section{Introduction}

River basin developmental activities such as construction of dams/reservoirs, irrigation development, regulation of river flows, or land cover change often result in either a positive or negative impact on the hydrology of the river basin. Such activities require impact assessment to be performed before the developmental plans are commenced. However, most of the basins in developing countries, where basin developmental activities are currently being carried out, are ungauged (Sivapalan, 2003), and data on key hydrologic variables such as rainfall, stream discharge, and evapotranspiration are unavailable, limited, or of poor quality. Thus, with limited in situ data, it becomes extremely difficult to carry out impact assessment studies. Challenges and issues pertaining to the

Published by Copernicus Publications on behalf of the European Geosciences Union. 
hydrologic predictions in ungauged basins have been extensively discussed (Sivapalan, 2003; Seibert and Beven, 2009). Lake Turkana, the largest desert lake in the world, is fed by ungauged or poorly gauged river systems. Since it is a closedbasin lake (endorheic lake), the fluctuations are determined by the influx from rivers and by the evaporation from the lake surface. Out of the three rivers (Turkwel, Keiro, and Omo) that contribute to the lake, the Omo River contributes more than $80 \%$ of the Lake Turkana inflows (Ricketts and Johnson, 1996). The Ethiopian government is building a series of dams on the Omo River primarily to generate electricity. These dams, the Gibe I, Gibe II, and Gibe III (under construction), regulate the flow of the Omo River and its tributaries that eventually flow into Lake Turkana.

The Gibe I dam (commissioned in 2004) is the first of the three hydroelectric projects built within the Ethiopian side of the Lake Turkana basin (Fig. 1). It is built on the Gilgel Gibe River, a small tributary of the main Gibe River, which flows into the Omo River. The Gibe II (commissioned in 2010) receives the water impounded by the existing Gibe I hydroelectric plant through a $26 \mathrm{~km}$ long tunnel directly into the Gibe-Omo River to a hydroelectric plant located $500 \mathrm{~m}$ below Gibe I elevation. The resulting head is used to generate electric power. As this project does not impound any water by itself, we assume it has no significant impact on the Lake Turkana water levels. The Gibe III dam is located on the Omo River about $150 \mathrm{~km}$ downstream of the Gibe II outlet (Fig. 1). Near the dam, the area is characterized by a large plateau with a long and relatively narrow canyon through which the river flows (The Gilgel Gibe Affair, 2008). Upon completion, a $150 \mathrm{~km}$ long lake (a valley dammed reservoir) would be created, flooding the whole canyon from the dam upstream to the Gibe River and retaining about 14.7 billion $\mathrm{m}^{3}$ of water at maximum capacity. The dam is expected to be commissioned by 2014 . The mean annual inflows into the reservoir are estimated to be $438 \mathrm{~m}^{3} \mathrm{~s}^{-1}$ (13800 million $\mathrm{m}^{3} \mathrm{yr}^{-1}$ ), with seasonal inflows varying from less than a $62 \mathrm{~m}^{3} \mathrm{~s}^{-1}$ in March to over $1500 \mathrm{~m}^{3} \mathrm{~s}^{-1}$ in August (EEPCo, 2009). The impact of the Gibe III dam on Lake Turkana is still not clearly understood. As the Turkana basin is poorly gauged, the availability of in situ gauge data on hydrologic parameters such as rainfall, streamflow, and evapotranspiration (ET) are very limited. However, satellite sensors provide data over large areas with consistent and repeated temporal coverage and thus offer several advantages in ungauged basins, so in this study we use a multi-source approach driven by satellite data to assess the potential hydrological impact of the Gibe III dam on Lake Turkana water levels.

Recently, a few studies/reports on the impact of Gibe III have become available (ARWG, 2009; EEPCo, 2004, 2009; Avery, 2010; Salini, 2010). However, there has not been consistency in the results obtained. Ethiopian Electric Power Corporation (EEPCo) performed an environmental impact assessment study of the Gibe II hydroelectric project and indicated that Lake Turkana will benefit from the Gibe I and

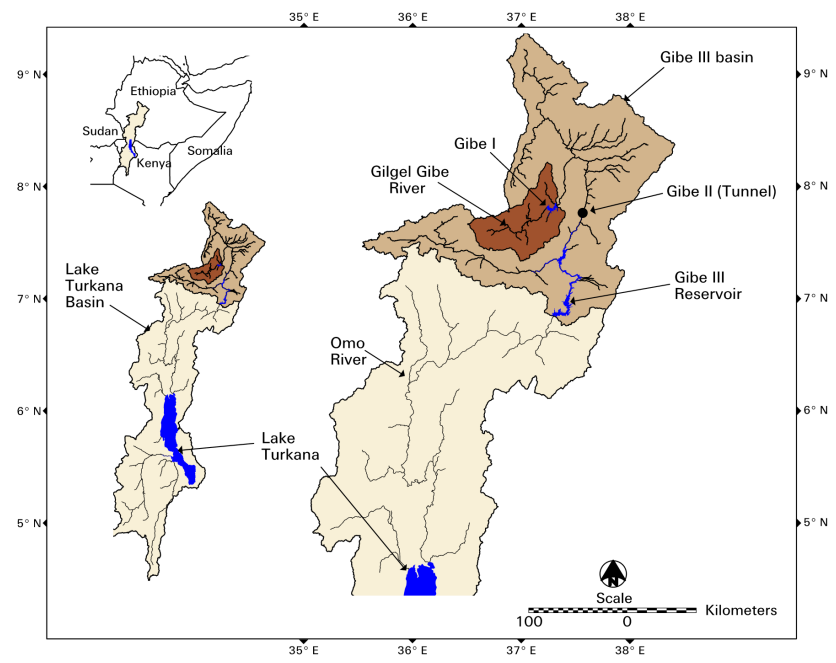

Fig. 1. Study area showing Lake Turkana and its watershed; location of Gibe dams on the Omo River, Ethiopia, are also shown.

Gibe II projects (EEPCo, 2004). Africa Resources Working Group (ARWG) provided a commentary on the environmental and socioeconomic impact assessment of the Gibe III dam and indicated that the lake would drop up to 10$12 \mathrm{~m}$ (ARWG, 2009). EEPCo (2009) indicated only that the Gibe III dam would have a positive impact on the lake. Recently, Avery (2010) published the most comprehensive report on Lake Turkana and identified that the dam would cause up to a $2 \mathrm{~m}$ level drop in the Lake Turkana level. Furthermore, Salini (2010), the agency building the dam, reported that initially lake water levels would drop up to $1.5 \mathrm{~m}$. Some limitations of these studies are a lack of consistent methodology and a failure to model the impact beyond the initial period of dam filling. In this study, we present the impact assessment study that uses remotely sensed data and hydrologic modeling techniques to model the potential hydrological impact beyond the initial period of dam filling.

\subsection{Objectives of this study}

The objectives of this study are (i) to demonstrate the use of a calibrated multi-source satellite-driven water balance model to assess potential interactions between Lake Turkana and the Gibe III dam, (ii) to use existing satellite data (19982009) to model the potential impact of Gibe III dam, (iii) to study the response of Lake Turkana to regulated inflows from the dam under different operational strategies, and (iv) to model the impact of the Gibe III dam on lake shoreline changes and identify vulnerable areas of change along the shoreline. In this study, we used three different approaches to simulate rainfall-runoff scenarios to study the potential hydrologic interactions between the Gibe III dam and Lake Turkana water levels. 


\section{Study area and data used}

\subsection{Study area}

The study is conducted over the Lake Turkana basin, which extends over Ethiopia in the north, Kenya in the south, and Sudan and Uganda in the west (Fig. 1). Lake Turkana is one of the lakes in the Great Rift Valley of East Africa. It has a maximum depth of nearly $110 \mathrm{~m}$ and an average depth of $30 \mathrm{~m}$, and extends up to $250 \mathrm{~km}$ long and $15-30 \mathrm{~km}$ wide, with an average surface area of nearly $6750 \mathrm{~km}^{2}$. Lake Turkana is known for its inter- and intra-annual fluctuations. The climate of Lake Turkana is hot, arid, and moderately stable all year. The driest months are from October through January and rainfall occurs from April through August. The average rainfall over the lake is less than $200 \mathrm{~mm} \mathrm{yr}^{-1}$ (Halfman and Johnson, 1988). Seasonal variations in rainfall over the Omo River catchment cause a high influx of water during July-December. Thus, the lake shows minimum water levels during June-July and maximum levels during SeptemberNovember. Generally, the lake level fluctuates annually with an amplitude of about $1-1.5 \mathrm{~m}$, but it also undergoes considerable long-term variations when compared to other rift valley lakes in Africa (Butzer, 1971). Nyamweru (1989) suggested that the lake levels were about $80 \mathrm{~m}$ higher than the present levels when the lake was connected to the Nile during the Holocene period. Kallqvist et al. (1988) synthesized the Lake Turkana water levels for the last $100 \mathrm{yr}$ and summarized that around 1895, the lake was $20 \mathrm{~m}$ higher than the present, followed by a general decline during the first half of the 20th century. After a minimum in the 1950s, there was a rapid increase up to late 1970s. The modern lake has no outlet and the lake fluctuates from about $360 \mathrm{~m}$ to $365 \mathrm{~m}$ above sea level (a.s.l.). The most recent water level fluctuations captured by TOPEX/Poseidon (Cretaux et al., 2011) show that the lake levels gradually increased to reach a level of $365 \mathrm{~m}$ a.s.l. by the end of the 20th century. The altimetry data show that lake levels by the end of 2011 were around $362.5 \mathrm{~m}$ a.s.l.

\subsection{Data used}

The data used in this study are summarized in Table 1. The National Oceanic and Atmospheric Administration (NOAA) Climate Prediction Center (CPC) produces satellite-based daily rainfall estimates (RFE). RFE data is available in nearreal time since 1995 with a spatial resolution of 0.1 degree. Validation studies of RFE over the Ethiopian highlands using gauge data suggested that RFE can be reliably used for early warning systems to empower the decision making process (Dinku et al., 2008; Beyene and Meissner, 2010). Reliable use of RFE data to model Lake Turkana water levels with reasonable accuracy was demonstrated by Velpuri et al. (2012). RFE data from January 1998 to December 2009 are used in this study. The daily reference evapotranspiration (ETo) data are produced at the USGS Earth Resources Observation and Science Center from 6-hourly Global Data Assimilation System (GDAS) climate parameters using the standardized Penman-Monteith equation, then downscaled to 0.1 degree for this study (Senay et al., 2008). Historical average dekadal Normalized Difference Vegetation Index (NDVI) datasets (1982-2006) described by Tucker et al. (2005) from the Advanced Very High Resolution Radiometer (AVHRR) are used to characterize the land surface phenology (LSP) and to estimate actual evapotranspiration (ETa) on a pixel-by-pixel basis at 0.1 degree resolution. The canopy interception parameter is estimated using the global percent tree cover product produced from Moderate Resolution Imaging Spectroradiometer (MODIS) Vegetation Continuous Field (Hansen et al., 2003). Area weighted average interception losses are estimated for each modeling pixel based on the percentage of bare, herbaceous, and tree cover for each pixel. The Digital Soil Map of the World (FAO, 1995) is used to estimate water holding capacity (WHC) for the dominant soil type for each grid cell at 1:5 million. Landsat data are used to delineate the Gibe I reservoir and Lake Turkana. Digital elevation models (DEM) from Shuttle Radar Topography Mission (SRTM) 90-m Version 4.0 and Advanced Spaceborne Thermal Emission and Reflection Radiometer (ASTER) global DEM (GDEM) $30 \mathrm{~m}$ Version 2.0 data are used to derive several hydrologic variables. Lake Turkana water level obtained from TOPEX/Poseidon (T/P), Jason-1/2, and ENVISAT altimetry data (Cretaux et al., 2011) was used for validation of the modeled lake levels.

\section{Methods}

\subsection{Deriving reservoir/lake depth-surface area-volume $(h-A-V)$ relationships}

In order to model the water levels, it is important to first understand the relationships between $h-A-V$ for each reservoir and Lake Turkana. As the SRTM DEM acquired in 2000 provided pre-dam elevation for both land and area submerged under the reservoir, it was used to generate the topographic-bathymetric (topo-bathy) data for the Gibe I reservoir. ASTER provided the high resolution pre-dam DEM data $(30 \mathrm{~m})$ for Gibe III, so it was used to generate the topo-bathy for the Gibe III reservoir. For Lake Turkana, bathymetry data obtained from Kallqvist et al. (1988) were draped on the SRTM DEM to develop seamless topo-bathy data. Finally, $h-A$ relationships were developed from the lake/reservoir topo-bathy data. Based on the water levels, a simple GIS-based model was used to extract surface areas at every $0.5 \mathrm{~m}$ interval of lake level. Thus, a relationship that explains the variations in $h-A$ were obtained. Similarly, changes in lake volumes $(V)$ were derived as 
Table 1. Satellite data, products, and other ancillary data used in this study.

\begin{tabular}{llllll}
\hline No & Data & Satellite Sensor/Source & Frequency & Resolution/Scale & Reference \\
\hline 1 & Rainfall estimate for Africa & SSM/I, AMSU & Daily & $0.1^{\circ} \times 0.1^{\circ}$ & $\begin{array}{l}\text { Herman et al. (1997); } \\
\text { Xie and Arkin (1996) } \\
\text { Senay et al. (2008) }\end{array}$ \\
2 & Global GDAS reference & Model assimilated & Daily & $0.1^{\circ} \times 0.1^{\circ}$ & \\
& Evapotranspiration (ET) & satellite data & & Tucker et al. (2005) \\
3 & Climatological NDVI & NOAA AVHRR & Dekadal & $8 \mathrm{~km}$ & - \\
4 & Landsat & TM/ETM & Multiple dates & $30 \mathrm{~m}$ & FAO (1995) \\
5 & Digital soil map of the world & National statistics & Single date & $1: 5000000$ & Hansen et al. (2003) \\
6 & Global percent tree cover map & MODIS VCF & Single date & $500 \mathrm{~m}$ & Farr and Kobrick (2000) \\
7 & Digital Elevation Model & SRTM V 4.0 & Single date & $90 \mathrm{~m}$ & Tachikawa et al. (2011) \\
8 & Digital Elevation Model & ASTER GDEM V 2.0 & Single date & $30 \mathrm{~m}$ & Birkett and Mason (1995) \\
9 & Lake Turkana water levels & TOPEX/Poseidon, Jason-1, & Daily & $>200 \mathrm{~m}$ & Kallqvist et al. (1988) \\
10 & Lake Turkana bathymetry data & ENVISAT & Single date & - & EEPCo (2009) \\
11 & Omo River inflow data & EEPCo (2009) & 1964-2001 & - & \\
\hline
\end{tabular}

$V=\sum_{i=1}^{N}\left[\left(D-\mathrm{LTB}_{i}\right) \times A\right]$

where $D$ is the lake water level or depth [Length, $L$ ], LTB $_{i}$ is the bottom height $[L]$ for each pixel $i$ obtained from the topo-bathy data, $A$ is the pixel area $\left[L^{2}\right]$ of the topo-bathy data, and $N$ is the total number of pixels in the topo-bathy data representing the surface area of the reservoirs or lake at a given water level. Using Eq. (1), lake volumes at regular intervals were extracted and $h-V$ relationships were derived for the lake and Gibe reservoirs. Furthermore, SRTM elevation data were used to delineate hydrologic variables such as (a) the Lake Turkana watershed, (b) catchment areas, and (c) streams and river networks.

\subsection{Lake level modeling approach}

In this paper we use the lake level modeling approach presented by Velpuri et al. (2012). This approach uses a multisensor multi-source approach to monitor lake water levels by integrating digital elevation data, satellite-based rainfall estimates, modeled ET, runoff data, and other satellite products. Lake levels modeled using this approach were found to be reasonable with $<10 \%$ errors when compared to satellite altimetry data (Velpuri et al., 2012). We introduced the Gibe I and Gibe III dams into the lake level modeling approach and routed the runoff through dams before reaching the lake. Furthermore, operational strategies of the Gibe I and Gibe III dams are also incorporated with the lake level modeling approach.

\subsubsection{Modeling runoff and ET}

First, satellite rainfall and ET data are used to estimate runoff [Length/Time, $L / T$ ] on a pixel-by-pixel basis using the phenology-based model called VegET (Senay, 2008;
Senay et al., 2009). The unique aspect of this model is the use of remotely sensed land surface phenology (LSP) to parameterize the spatial and temporal dynamics of ET and runoff on a grid-cell basis. Then VegET model estimates runoff $\left(Q_{\mathrm{rf}}\right)$ for each time step based on the principle of soil saturation excess, where soil water content in excess of the WHC of the soil is considered runoff. The VegET model can be explained by Eqs. (2) and (3):

$\mathrm{ET}_{\mathrm{a}}=K_{\mathrm{cp}} \times K_{\mathrm{s}} \times \mathrm{ET}_{\mathrm{o}}$

$Q_{\mathrm{rf}, i}=\left[\mathrm{SW}_{(i-1)}+\left(\left(1-\mathrm{ILC}_{i}\right) \times \mathrm{RFE}_{i}\right)-\mathrm{ET}_{\mathrm{a}_{i}}\right]-\mathrm{WHC}_{i}$

where $\mathrm{ET}_{\mathrm{a}}$ is the actual ET; $K_{\mathrm{cp}}$ is the LSP-based crop coefficient; $K_{\mathrm{S}}$ is the soil water stress coefficient (0-1) whose value depends on the state of soil water on a daily basis; $\mathrm{ET}_{\mathrm{o}}$ is the global GDAS reference ET; RFE is the satellitebased rainfall estimate; and SW represents soil water content. ILC $_{i}$ is the interception losses coefficient, WHC is the water holding capacity of the soil determined as the difference between the field capacity and wilting point in the top one meter of soil, subscript $i$ represents the current modeling time step, and subscript $i-1$ represents the previous time step. To avoid negative outcomes, runoff is considered as 0 when $Q_{\mathrm{rf}, i}$ is negative. This approach produces a combined daily estimate of surface runoff and deep-drainage. Variables $\mathrm{ET}_{\mathrm{a}}, \mathrm{ET}_{\mathrm{o}}$, RFE, and SW all are in units $[L / T]$. Further description of this approach is found in Senay (2008); Senay et al. (2009); and Velpuri et al. (2012). Runoff generated using this approach is routed using a source-to-sink routing algorithm (Asante, 2000; Olivera et al., 2000; Velpuri et al., 2012) and total routed runoff volume contribution for each basin $\left(Q_{\text {inf }}\right)$ is produced as outlined in Velpuri et al. (2012).

\subsubsection{Calibration of runoff data}

In order to accurately predict the volumetric changes in reservoirs and the lake, it is essential to calibrate modeled 
runoff/inflow data using ground-based observation. It is common knowledge that all satellite-based rainfall estimates show bias when compared to ground truth data (Dinku et al., 2008), which would propagate into modeled runoff estimates. Hence, through calibration of modeled runoff, we aim to perform (a) base flow and (b) bias correction for modeled runoff estimates. EEPCo (2009) published longterm (1964-2001) mean monthly Omo River flow data at the Gibe III site and at Lake Turkana. We used these data to calibrate modeled inflows for Gibe I, Gibe III, and Lake Turkana such that the calibrated data (1998-2009) would follow the long-term distribution (trend and magnitude) of the historical data (1964-2001). This is based on the assumption of stationarity of lake inflows, which means that longterm mean inflows into the lake have not changed. This assumption holds good as trends in annual and seasonal rainfall have not undergone any significant change in the region (Seleshi and Zanke, 2004; Cheung et al., 2008). First, we estimated base flow from the long-term mean monthly hydrographs using a constant discharge method (Linsley et al., 1975) for Gibe III and Turkana. By comparing long-term mean (1964-2001) streamflow data with mean monthly modeled runoff (1998-2009), monthly parameters for bias correction were obtained. Estimates of base flow and monthly coefficients for bias correction were used to calibrate modeled Gibe III basin runoff data for 1998-2009. We used bias correction coefficients obtained for the Gibe III basin to calibrate modeled runoff for the Gibe I basin (a sub-basin of Gibe III). Base flow information for Gibe I was obtained from EEPCo (2004). Since contributions from other rivers in the Turkana basin (Turkwel and Kerio) are negligible (Carr, 1998), we calibrated the combined Omo, Turkwell, and Kerio inflows with the long-term mean monthly inflow data for the Omo River at Turkana. For the Gibe III basin, $4 \mathrm{yr}$ of monthly flow data (1998-2001) were used to validate calibrated runoff. For Lake Turkana, only long-term mean monthly Omo River flow data were available, so validation could not be performed.

\subsubsection{Modeling Gibe I, Gibe III, and Lake Turkana water levels}

Total daily over-the-lake/reservoir rainfall $\left(Q_{\text {rain }}\right)$, ET ( $\left.Q_{\text {evap }}\right)$ and the runoff volume contribution $\left(Q_{\text {inf }}\right)$ were extracted. The lake level information for each time step is then estimated using a water balance principle as shown in Eqs. (4)-(7). First, daily Gibe I reservoir levels are modeled as

$$
\begin{array}{r}
\frac{\Delta L_{i}}{\Delta t}(G 1)=Q_{\mathrm{rain}, i}(G 1)+Q_{\mathrm{inf}, i}(G 1) \\
-Q_{\mathrm{evap}, i}(G 1)-Q_{\mathrm{out}, i}(G 1)
\end{array}
$$

where $\Delta L_{i} / \Delta t$ represents change in water levels per unit time step; $G 1$ represents the Gibe I reservoir and $Q$ represents different fluxes for the current time step, $i$; "rain" $[L / T]$ is the direct rainfall over the reservoir; "inf" is the incoming calibrated runoff contribution to the reservoir; "evap" $[L / T]$ is the over-the-lake evaporation; "out" $[L / T]$ is the outflow from the Gibe I reservoir that will eventually flow into the Gibe III reservoir. Actual water levels for the current time step are obtained by adding change in depth from the previous time step. Then, daily Gibe III reservoir levels are modeled as

$$
\begin{gathered}
\frac{\Delta L_{i}}{\Delta t}(G 3)=Q_{\text {rain }, i}(G 3)+Q_{\text {inf }, i}(G 3)+Q_{\text {out }, i}(G 1) \\
-Q_{\text {evap }, i}(G 3)-Q_{\text {out }, i}(G 3)
\end{gathered}
$$

where $G 3$ represents the fluxes of the variables for the Gibe III reservoir; According to EEPCo (2007), contribution of groundwater fluxes or seepage losses to and from the reservoirs are minimal. Hence, we ignored groundwater fluxes in Eqs. (4) and (5). $G 3 Q_{\text {out }}$, the surface outflow from the Gibe III reservoirs is estimated as

$$
\begin{aligned}
G 3 Q_{\mathrm{out}, i} & =G 3 Q_{\mathrm{env}, i}+G 3 Q_{\text {flood }, i}+G 3 Q_{\mathrm{pp}, i} \\
& +G 3 Q_{\mathrm{spill}, i}
\end{aligned}
$$

where $G 3 Q_{\text {env }}[L / T]$ is the environmental flows; $G 3 Q_{\text {flood }}$ $[L / T]$ is the artificial flood released from Gibe III; $G 3 Q_{\mathrm{pp}}$ $[L / T]$ is the water discharged from the Gibe III power plant; and $G 3 Q_{\text {spill }}[L / T]$ represents spill flow or excess flow released when the Gibe III dam is at maximum level, which will eventually flow downstream into Lake Turkana. Finally, Lake Turkana water level is estimated as

$$
\begin{aligned}
\frac{\Delta L_{i}}{\Delta t}(\mathrm{LT}) & =Q_{\text {rain }, i}(\mathrm{LT})+Q_{\mathrm{inf}, i}(\mathrm{LT})+Q_{\mathrm{out}, i}(G 3) \\
& -Q_{\text {evap }, i}(\mathrm{LT}) \pm \varepsilon
\end{aligned}
$$

where LT represents the fluxes of the variables for Lake Turkana; and $\varepsilon[L / T]$ is the error term that accounts for the data and modeling errors. The estimate of $\varepsilon\left(-2 \mathrm{~mm} \mathrm{day}^{-1}\right)$ for Lake Turkana obtained by Velpuri et al. (2012) is used in this study. As Lake Turkana is a considered closed lake (Ricketts and Johnson, 1996), groundwater inflows and surface outflows are considered negligible (Cerling, 1986). Finally, for each Gibe I, Gibe III and Lake Turkana, water level for the current time step is obtained by adding change in water level for the current time step with the water level from the previous time step. A detailed description of the lake level modeling approach is provided in Velpuri et al. (2012).

\subsection{Operational strategies of the Gibe dams}

In this study, to simulate the potential hydrological impact of the dams we considered the operational strategies to be followed by EEPCo. Below are the operational strategies for the Gibe I and Gibe III dams that are implemented in the modeling framework.

a. The rated outflow of $101.5 \mathrm{~m}^{3} \mathrm{~s}^{-1}$ and a continuous environmental flow of $1.3 \mathrm{~m}^{3} \mathrm{~s}^{-1}$ are released downstream of the Gibe I dam (EEPCo, 2004). 
b. Continuous environmental flow of $25 \mathrm{~m}^{3} \mathrm{~s}^{-1}$ will be released from the Gibe III dam (EEPCo, 2009).

c. To maintain the natural flooding conditions in the lower Omo basin, an artificial flood at the rate of $1000 \mathrm{~m}^{3} \mathrm{~s}^{-1}$ will be released from the Gibe III for 10 days in September (EEPCo, 2009).

d. The minimum operating level for the start of power generation is $854 \mathrm{~m}$ a.s.l. or $201 \mathrm{~m}$ of reservoir depth (EEPCo, 2009).

e. The hydroelectric power plant would operate for 11 out of $24 \mathrm{~h}$ a day; i.e., a plant factor of 0.46 would be used to estimate the total power produced (Salini, 2010).

Water level in each reservoir is estimated using Eqs. (4) and (5). Based on the water level, outflows from each dam are estimated following the operational strategies. Finally, Lake Turkana inflows are combined with the outflows from the reservoirs to estimate lake level height as shown in Eq. (7).

\subsection{Gibe III Impact assessment using satellite data}

Since Gibe III was not commissioned at the time of this study, we used existing satellite-based estimates of hydrologic variables to forecast the potential hydrological impact of the Gibe III dam. The relatively short length of the available satellite data (1998-2009) precludes a complete characterization of the rainfall variability in the basin. This is a common problem especially in ungauged basins where in situ data are either limited or unavailable. However, the modeled lake inflows are calibrated using long-term (1964-2001) mean monthly Omo River discharge data to minimize the impact of bias in the satellite rainfall and in the resulting modeled runoff estimate. Despite the short time series, we argue that the calibrated runoff would approximate the distribution (trend and magnitude) of the observed historical data (19642001). Furthermore, the rainfall variability observed over the $12 \mathrm{yr}$ period (1998-2009) could represent much of the seasonal and annual rainfall-runoff distribution of the basin. We used three different approaches to simulate rainfall-runoff scenarios and evaluate the potential impact of the dam on Lake Turkana.

\subsection{Approach I - historical approach}

In this approach we assumed a simple case that the Gibe III dam was commissioned sometime in the past (January 1998). First, using the lake level modeling approach (Velpuri et al., 2012), Lake Turkana water levels for 1998-2009 were modeled without the dam. Then, the model was rerun assuming that the Gibe III Dam was commissioned on 1 January 1998, and the volume of the inflows routed through the dam was used to model lake levels. A comparison of the volume of inflows and the lake water levels with and without the dam yielded the impact of the Gibe III dam. Furthermore, the time taken for the Gibe III reservoir to reach minimum operation level (MOL) and loss in Lake Turkana water level was estimated.

\subsection{Approach II - sampling techniques}

\subsubsection{Rainfall based sampling}

Rainfall variability in the East African region has been thoroughly investigated (Kolding, 1992; Camberlin et al., 2001; Shongwe et al., 2009). Kolding (1992) studied the rainfall distribution over Lake Turkana and summarized that severe drought occurs roughly every $6 \mathrm{yr}$. The summer rains in this region were found to be significantly correlated to the ElNiño Southern Oscillation (ENSO), which repeats on average every 5 yr (Camberlin et al., 2001). Furthermore, Shongwe et al. (2009) reported that there has been an increase in the number of reported hydro-meteorological disasters in the region, from an average of $<3$ events per year in the 1980s to $\sim 10$ events per year from 2000 to 2006 , with a particular increase in floods. A quick analysis of rainfall data over 1998-2009 shows that there was a severe drought in 2000 (WFP, 2000) and below normal rainfall in 2003, 2004, 2005, and 2009. There were incidents of heavy rainfall due to the ENSO effect in 1998 (Behera, et al., 2005) and severe floods in 2006 (Moges et al., 2010), whereas above normal rainfall was observed in 2001, 2002, and 2006. Other years, 1999, 2007, and 2008, had near normal rainfall. These observed patterns grossly follow the trend observed by Kolding (1992) and Camberlin et al. (2001), with one severe drought (2000) and 2 severe rainfall years (1998 and 2006). However, other patterns of below normal and above normal rainfall years could be explained by the observations made by Shongwe et al. (2009). Based on the knowledge of the rainfall distribution in the region, 20 different scenarios of above normal, near normal, and below normal rainfall distributions were built such that the occurrence of a severe drought year (2000) or a severe flood year (2006) would not occur more than twice or, in rare cases, three times in a $12 \mathrm{yr}$ scenario. The choice of other years was purely based on random selection without any constraints. Table 2 shows various combinations of years under each scenario used. Under each scenario, simulations of lake levels were modeled and compared with and without the dam. Furthermore, the time taken for the Gibe III reservoir to reach MOL and subsequent loss in Lake Turkana water level was estimated.

\subsubsection{Statistical approach}

There are several statistical approaches available that can be used to generate time series information of climate variables using historical data (Srikanthan and McMahon, 2001). However, most statistical approaches assume that the underlying variable is normally distributed, a requirement that is not generally met by most hydrologic data (Salas et al., 
Table 2. Scenarios of rainfall generated based on the rainfall based scenarios in the East African region.

\begin{tabular}{|c|c|c|c|c|c|c|c|c|c|c|c|c|c|c|c|c|c|c|c|c|}
\hline \multirow{2}{*}{ Years } & \multicolumn{20}{|c|}{ Rainfall based scenarios } \\
\hline & 1 & 2 & 3 & 4 & 5 & 6 & 7 & 8 & 9 & 10 & 11 & 12 & 13 & 14 & 15 & 16 & 17 & 18 & 19 & 20 \\
\hline Y1 & 2005 & 2000 & 2009 & 2000 & 2008 & 2006 & 1998 & 1998 & 2008 & 2009 & 2009 & 1998 & 2009 & 2001 & 2006 & 2003 & 2004 & 2003 & 2000 & 2001 \\
\hline $\mathrm{Y} 2$ & 2009 & 2002 & 2002 & 1998 & 2000 & 2001 & 2004 & 2000 & 1999 & 2001 & 2006 & 2004 & 2007 & 2006 & 2005 & 2000 & 2009 & 1998 & 2000 & 1998 \\
\hline Y3 & 2007 & 2006 & 2006 & 2004 & 1998 & 2006 & 2005 & 2007 & 2005 & 2003 & 2005 & 2000 & 2000 & 2002 & 2004 & 2002 & 2000 & 2007 & 2004 & 2000 \\
\hline Y4 & 2000 & 2004 & 2005 & 2001 & 2004 & 2001 & 2009 & 2002 & 2006 & 2006 & 2000 & 2006 & 2003 & 2003 & 1999 & 1998 & 2007 & 2009 & 2007 & 2002 \\
\hline Y5 & 2006 & 2009 & 1998 & 2000 & 2000 & 2007 & 2000 & 2000 & 1999 & 2008 & 2004 & 2001 & 2005 & 1998 & 2003 & 2000 & 2004 & 2006 & 1999 & 2007 \\
\hline Y6 & 2001 & 1998 & 2009 & 2009 & 2009 & 2009 & 2009 & 2008 & 2004 & 2003 & 2005 & 2007 & 2009 & 2002 & 2000 & 2008 & 2008 & 2003 & 2004 & 2001 \\
\hline Y7 & 2004 & 2001 & 2002 & 2001 & 2002 & 1998 & 2005 & 2001 & 2002 & 2007 & 2004 & 2009 & 2006 & 2005 & 2002 & 2000 & 1998 & 2002 & 2006 & 2006 \\
\hline Y8 & 2002 & 2009 & 2003 & 2007 & 2008 & 2001 & 2008 & 2004 & 2004 & 2008 & 2000 & 2002 & 2000 & 1998 & 1999 & 2002 & 2005 & 2005 & 2001 & 2003 \\
\hline Y9 & 1998 & 2000 & 2000 & 2002 & 2006 & 2004 & 2006 & 1999 & 2000 & 2009 & 2001 & 1999 & 1998 & 2007 & 2004 & 2002 & 2000 & 2000 & 2007 & 2005 \\
\hline Y10 & 2004 & 2000 & 2002 & 2006 & 2005 & 2000 & 2005 & 2001 & 2008 & 2009 & 2008 & 2000 & 2004 & 2007 & 2007 & 2006 & 2008 & 2008 & 2008 & 2005 \\
\hline Y11 & 2000 & 2001 & 2001 & 2007 & 2007 & 2002 & 2000 & 2006 & 2001 & 2006 & 2006 & 2004 & 2002 & 2009 & 1998 & 2001 & 2004 & 2002 & 2009 & 2003 \\
\hline Y12 & 2002 & 2003 & 2007 & 2008 & 2004 & 2003 & 2005 & 2008 & 2007 & 2001 & 2007 & 1998 & 1999 & 2000 & 2003 & 2008 & 2006 & 2005 & 2006 & 2000 \\
\hline
\end{tabular}

2006). Unlike traditional parametric models, nonparametric approaches are data driven, and they do not assume a particular statistical distribution (Wilks and Wilby, 1999). Furthermore, $12 \mathrm{yr}$ of data (1998-2009) is not sufficient to describe the statistical distribution. Hence, we used $12 \mathrm{yr}$ of data to simulate time series information on the possible scenarios of rainfall, lake inflows, and ET data using the nonparametric bootstrap resampling (NBR) technique. NBR is a distribution-independent resampling procedure that provides an indirect method to assess the properties of the distribution underlying the sample. Often the Monte Carlo method is used to draw a large number of samples "with replacement". The NBR technique was first introduced by Efron and Tibshirani (1993) and has been widely used for the simulation of rainfall or inflows using historical data (Rajagopalan et al., 1997; Lall and Sharma, 1996; Srikanthan and McMahon, 2001). This approach is useful for simulating data in ungauged basins where such simulated data is required to analyze the impact of alternative designs, operation policies, and other rules. Different methods of NBR are available. In this study, we used a simple NBR approach where the time series data of future scenarios of lake inflows are drawn at random from the data (1998-2009) numerous times using the Monte Carlo approach. Since we are using existing/historic data to predict future scenarios, the resampled scenarios represent plausible future scenarios under the assumption that the future would have similar statistical properties as the observed data. Furthermore, since observations are randomly resampled (with replacement), serial dependence is not preserved in a simple NBR approach. However, since we ran the simulation a large number of times using the Monte Carlo approach, the impact of different combinations of daily runoff including the scenarios with serial dependency is most likely to be captured within the range of the simulated data. Moreover, since we bag the daily data from the 12 different years and randomly draw a value from the set of observations for a given day, the seasonal pattern of observed rainfall is preserved. In this study, the main reason for using the NBR approach is to construct confidence intervals around the mean Lake Turkana water levels due to moderated flows from Gibe III under different future scenarios of rainfall. The NBR is mathematically explained in the following steps:

- Step 1: let the parameter of interest (rainfall or runoff or ET variables for Gibe I, Gibe III and Turkana basins) be represented by the vector $Q_{v, i}$, where the subscript $v$ denotes index for $12 \operatorname{yr}(v=1,2, \ldots 12)$ and $i$ denotes the series of daily data for a year $(i=1,2,3, \ldots 365)$. Then the $\mathbf{X}$-matrix for $12 \mathrm{yr}$ of data can be shown as

$$
\mathbf{X}=\left[\begin{array}{ccccc}
Q_{1,1} & Q_{1,2} & \ldots & \ldots & Q_{1,365} \\
Q_{2,1} & Q_{2,2} & \ldots & \ldots & Q_{2,365} \\
\ldots & \ldots & \ldots & \ldots & \ldots \\
\ldots & \ldots & \ldots & \ldots & \ldots \\
Q_{12,1} & Q_{12,2} & \ldots & \ldots & Q_{12,365}
\end{array}\right]
$$

- Step 2: for each day of the year, the bootstrap resample is drawn with replacement from the corresponding column of data in Eq. (8) to build a matrix of resampled time series shown as

$$
\mathbf{X}^{*}=\left[\begin{array}{ccccc}
Q_{1,1}^{*} & Q_{1,2}^{*} & \ldots & \ldots & Q_{1,365}^{*} \\
Q_{2,1}^{*} & Q_{2,2}^{*} & \ldots & \ldots & Q_{2,365}^{*} \\
\ldots & \ldots & \ldots & \ldots & \ldots \\
\ldots & \ldots & \ldots & \ldots & \ldots \\
Q_{12,1}^{*} & Q_{12,2}^{*} & \ldots & \ldots & Q_{12,365}^{*}
\end{array}\right]
$$

where $\mathbf{X}^{*}$ represents the resampled data matrix and $Q_{v, i}^{*}$ is a random sample for a day of the year equal to any of the 12 values for a particular day (a column of variables) in Eq. (8).

- Step 3: using the lake level modeling approach and independent matrices of resampled variables $Q_{v, i}^{*}$ generated in step 2,12 yr of lake water levels are modeled on a daily basis, by modifying Eqs. (4), (5), and (7) as

$$
\begin{gathered}
\frac{\Delta L_{v, i}^{*}}{\Delta t}(G 1)=Q_{\text {rain }}^{*}(G 1)+Q_{\text {inf }}^{*}(G 1)-Q_{\text {evap }}^{*}(G 1) \\
+Q_{\text {out }}(G 1)
\end{gathered}
$$




$$
\begin{aligned}
\frac{\Delta L_{v, i}^{*}}{\Delta t}(G 3) & =Q_{\text {rain }}^{*}(G 3)+Q_{\text {inf }}^{*}(G 3)+Q_{\text {out }}(G 3) \\
& +Q_{\text {evap }}^{*}(G 3)-Q_{\text {out }}(G 3)
\end{aligned}
$$

$$
\begin{aligned}
\frac{\Delta L_{v, i}^{*}}{\Delta t}(\mathrm{LT}) & =Q_{\text {rain }}^{*}(\mathrm{LT})+Q_{\text {inf }}^{*}(\mathrm{LT}) \\
& +Q_{\text {out }}(\mathrm{LT})-Q_{\text {evap }}^{*}(\mathrm{LT}) \pm \varepsilon
\end{aligned}
$$

- Step 4: a large number of combinations are possible $\left(12^{365}\right)$ to build data for a year (a row in Eq. 9). Hence, steps 1 through 3 are repeated numerous times $(B=$ 100000 times), such that time series data matrices for daily variables (rainfall, runoff, and ET) are used to generate a total of $B$ independent arrays of lake levels as $\left(L^{*}\right)^{(1)},\left(L^{*}\right)^{(2)} \ldots\left(L^{*}\right)^{(B)}$.

- Step 5: a $95 \%$ confidence interval for a total of $B$ estimates of $L_{v, i}^{*}$ is obtained by sorting individual estimates of $L_{v, i}^{*}$ in increasing order, such as $\left(L_{v, i}^{*}\right)^{(1)} \leq$ $\left(L_{v, i}^{*}\right)^{(2)} \ldots \leq\left(L_{v, i}^{*}\right)^{(B)}$. Then, the lower (LCI), median, and upper (UCI) bootstrap percentile $95 \%$ confidence intervals for $L_{v, i}^{*}$ are estimated as described in Efron and Tibshirani (1993).

\subsubsection{Cross-validation of lake levels modeled using NBR technique}

Velpuri et al. (2012) demonstrated the use of altimetry based lake level data for model validation especially when in situ data are unavailable. Lake levels modeled using the lake level modeling approach based on NBR variables were crossvalidated using altimetry based monthly lake level data obtained from TOPEX/Poseidon (T/P), Jason-1, and ENVISAT (Cretaux and Birkett, 2006; Cretaux et al., 2011). First, we ran the model to predict lake levels under natural conditions (without Gibe III) for a particular year using data from other years (i.e., predicting lake levels for 2006 using data from 1998-2005 and 2007-2009). Modeled lake level data were summarized on a monthly basis to enable direct comparison with the satellite altimetry data. The correlation between the predicted and altimetry data is presented in Fig. 5.

\subsubsection{Impact of the Gibe III dam based on the initial lake water levels}

Considering the Lake Turkana bathymetry and $h-A$ relationships, we hypothesize that the impact of the dam would depend on the initial lake water level at the time of commencement of the dam. This is because, the higher the lake level, the higher the surface area, and larger volumes of inflows are required to cause a unit increase in lake level. Similarly, we argue that when the initial lake water level is low, the lake would stabilize (reach initial lake level) faster with a lesser volume of inflows. We test this hypothesis by modeling lake levels with different initial lake levels.

\subsubsection{Application of NBR technique}

Using different scenarios of time series data produced, lake water levels for a period of $12 \mathrm{yr}$ from the commencement of the dam are produced using Eqs. (10), (11), and (12) considering both with and without the dam. The impact of the dam is assessed for different initial lake levels within the range of natural fluctuations of the lake (358-365 m). For each initial level, median, upper, and lower $95 \%$ confidence intervals of lake levels are summarized. The time required for the reservoir to reach MOL and loss in lake level during this period is also reported for each initial lake level.

\subsection{Analysis of shoreline changes using SRTM-based topo-bathymetry data}

The overall impact of the Gibe III dam in terms of lake shoreline is not completely understood unless the impact of frequency, timing, and duration of water level fluctuations on the lake shoreline are known. To derive lake shoreline changes, the lake level modeling approach is run (with initial lake level of $362 \mathrm{~m}$ a.s.1.) using median, upper, and lower $95 \%$ confidence intervals of lake levels each representing near normal, above normal, and below normal rainfall scenarios. Mean lake level and surface area are estimated for each month. Finally, mean lake surface areas of the lake for each month are combined to estimate the frequency of wetting and drying along the lake shoreline. Areas that are vulnerable to the fluctuations in the Lake Turkana water levels due to the impact of the Gibe III dam are identified. Furthermore, areas along the shoreline that are prone to repeated wetting and drying are also located.

\section{Results and discussion}

\subsection{Validation of calibrated lake inflow data}

Figure 2 shows the results of validation of calibrated modeled runoff using river gauge data at the Gibe III dam site over 1998-2001. Initial comparison of modeled and observed runoff at the Gibe III site shows that modeled runoff underestimates up to $49 \%$. This could be due to the underestimation of RFE data used in this study (Dinku et al., 2008), which is within the range of bias found in other satellite based rainfall products (Bitew and Gebremicheal, 2009; Dinku et al., 2010; Romily and Gebremicheal, 2011). Furthermore, modeled runoff data was also found to underestimate the base flow, especially during dry season months. Hence calibration of the modeled estimates for base flow and bias corrections was performed using long-term average monthly runoff data for (1964-2001). First, using constant discharge method, the base flow for Gibe III was estimated as $60 \mathrm{~m}^{3} \mathrm{~s}^{-1}$. Base flow estimate for Gibe I was obtained from EEPCo (2004). We used the percent area approach to validate the published base flow estimate for Gibe I using the base flow estimate for 


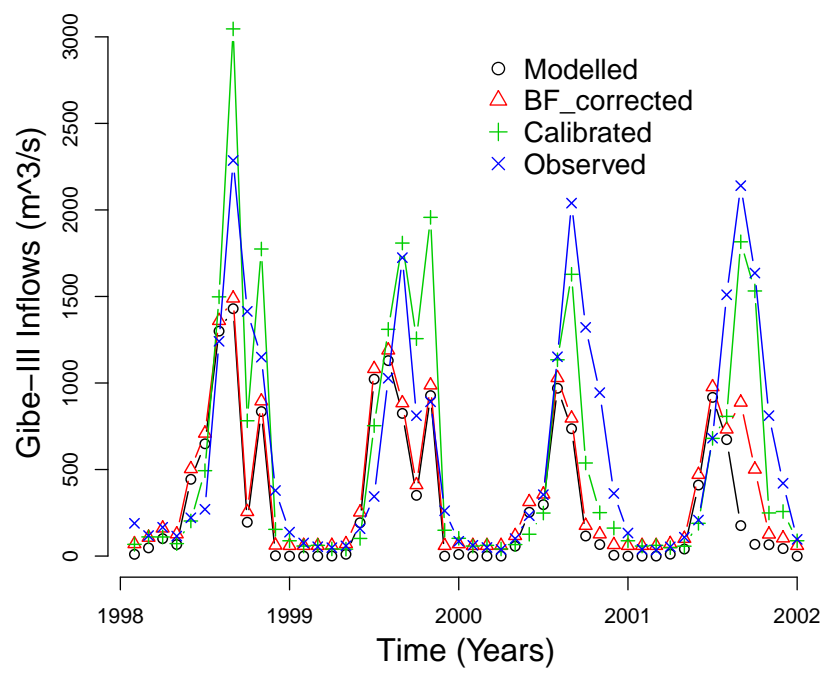

Fig. 2. Validation of calibrated modeled runoff data with observed monthly inflows (1998-2001) at the Gibe III dam site obtained from EEPCo (2009). Model calibrated using mean monthly streamflow data (1964-2001). Also shown are modeled (un-calibrated) and base flow corrected runoff data.

Gibe III. As the area of Gibe I is around one seventh of the Gibe III basin area, the base flow estimate for Gibe I was estimated as $8.2 \mathrm{~m}^{3} \mathrm{~s}^{-1}$. Thus the published base flow estimate was found to be reasonable.

We used modeled base flow estimates for Gibe I and III for the estimation of monthly correction factors for the Gibe and Turkana basins. The monthly correction factors demonstrated a seasonal pattern and were found to range from 0.5 to 2.0 for the Turkana basin and 0.5 to 3.0 for the Gibe I and Gibe III basins. As RFE underestimates by nearly $50 \%$, the monthly multiplier coefficients ranged up to 2.0 in the case of the Turkana basin. The correction coefficients for Gibe ranged up to 3.0 as RFE further underestimates rainfall in the mountainous regions during peak rainy seasons. After calibrating modeled runoff with in situ long-term average monthly data (1964-2001), simulated monthly runoff for 1998-2001 showed a reasonable match with the observed data with an $R^{2}$ of 0.77 and an improved bias of $-1.8 \%$.

\subsection{Surface area and volume estimates for the Gibe reservoirs and Lake Turkana}

The surface area and volume of the Gibe I reservoir modeled using SRTM based topo-bathy data was $49 \mathrm{~km}^{2}$ and 807 million $\mathrm{m}^{3}\left(\mathrm{Mm}^{3}\right)$, respectively, at a maximum operation level of $1671 \mathrm{~m}$ a.s.l. against the published surface area of $51 \mathrm{~km}^{2}$ and volume of $839 \mathrm{Mm}^{3}$ (EEPCo, 2004). The surface area of $209.3 \mathrm{~km}^{2}$ and total volume of 14.5 billion $\mathrm{m}^{3}$ at a maximum operation level of $894 \mathrm{~m}$ a.s.l. or $241 \mathrm{~m}$ were obtained for Gibe III using ASTER elevation data against the actual reported values of surface area $\left(210 \mathrm{~km}^{2}\right)$ and total volume (14.7 billion $\mathrm{m}^{3}$ ) as reported by EEPCo (2009). The surface area and volume obtained for Lake Turkana at $365 \mathrm{~m}$ a.s.l. are $7685 \mathrm{~km}^{2}$ and 233.4 billion $\mathrm{m}^{3}$, respectively. These values are in close agreement with lake surface area and volume published in the literature (Hopson, 1982).

\subsection{Evaporation losses from the Gibe reservoirs and Lake Turkana}

Quantifying evaporation losses from the Gibe reservoirs is very important as the water is lost from the reservoirs (consumptive use) and would never reach Lake Turkana. GDAS ETo was used to estimate the evaporation losses from Gibe I, Gibe III and Lake Turkana. Based on the analysis of GDAS ETo data from 2001-2009, we found that Gibe I and Gibe III would lose up to 1.34 and $1.46 \mathrm{~m}$ per year of water, respectively, due to evaporation. The evaporation loss of $1.46 \mathrm{~m}$ per year from Gibe III reservoir resulted in the reduction of Lake Turkana inflows by $10 \mathrm{~m}^{3} \mathrm{~s}^{-1}$. On the other hand, evaporation losses from Lake Turkana would account for up to 2.2 to $2.4 \mathrm{~m}$ per year.

\subsection{Approach I: historical approach}

The lake level modeling approach was run without the Gibe III dam to derive lake levels for the period 1998-2009. The lake level for 31 December 1997, was obtained from the altimetry data. Without Gibe III, the average rate of inflows into the lake was found to be $650 \mathrm{~m}^{3} \mathrm{~s}^{-1}$ during 1998-2009 with wet season flow rate over $1500 \mathrm{~m}^{3} \mathrm{~s}^{-1}$ and dry season flow rate of $100-200 \mathrm{~m}^{3} \mathrm{~s}^{-1}$ (Fig. 3a). The lake level fluctuated between 360 and $365 \mathrm{~m}$ a.s.l. during 1998-2009. The model was then rerun by commissioning the Gibe III dam on 1 January 1998. The model results show that because of the Gibe III dam, the peak flows into the lake are reduced and dry season flow is increased with a dam moderated average flow rate of $500-550 \mathrm{~m}^{3} \mathrm{~s}^{-1}$ including the initial impoundment period (Fig. 3a). Results indicated that the Gibe III reservoir would reach the MOL of $201 \mathrm{~m}$ in 8 months. During this period, the rate of inflow into Lake Turkana was found to be $58 \%$ less than the rate without the dam. However, after the initial impoundment period, the rate of inflows were found be around $640 \mathrm{~m}^{3} \mathrm{~s}^{-1}$, which is only $10 \mathrm{~m}^{3} \mathrm{~s}^{-1}$ less than average lake inflows without Gibe III. The difference between the lake levels with and without the dam was $0.65 \mathrm{~m}$ by the time the Gibe III reservoir reached MOL (Fig. 3b). The difference between the lake levels with and without dam conditions increased to slightly over $3 \mathrm{~m}$ by the beginning of 2000 (Fig. 3c). This is because of the combined result of (a) highly reduced lake inflows into the lake during initial impoundment $\left(550 \mathrm{~m}^{3} \mathrm{~s}^{-1}\right)$, (b) moderated inflows $\left(640 \mathrm{~m}^{3} \mathrm{~s}^{-1}\right)$ after Gibe III is full, and (c) evaporation losses from the lake (around $2 \mathrm{~m}$ ). After the year 2000, both the lake levels gradually declined until the middle of 2006 and increased by the end of 2007. The difference by the end of the $12 \mathrm{yr}$ simulation period was found to be $<1 \mathrm{~m}$. Figure 3 a shows a few 

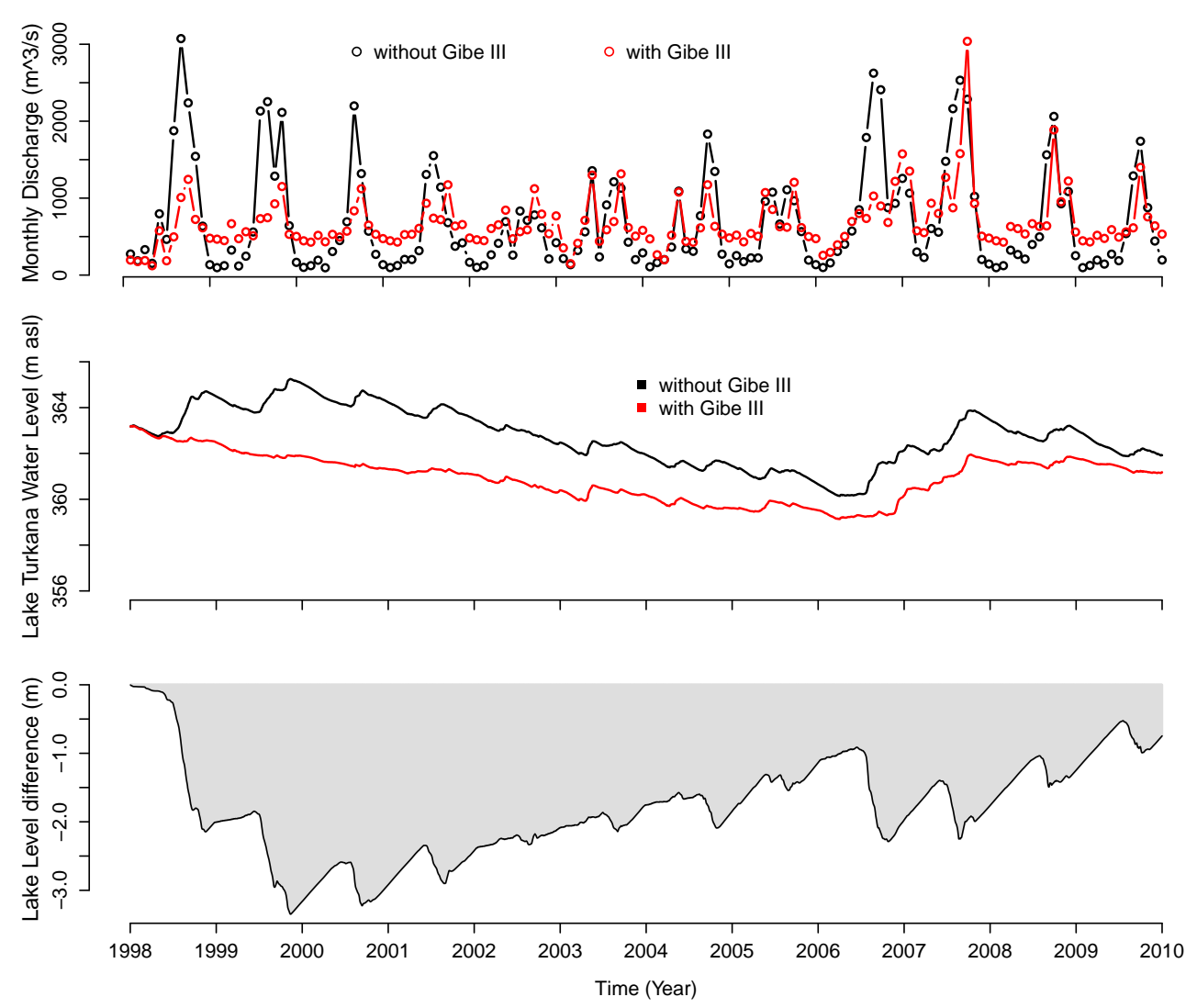

Fig. 3. Impact of the Gibe III dam evaluated using an historical approach. Top: total monthly Lake Turkana inflows; middle: the lake water levels; and bottom: the difference in lake levels. The model was run assuming the dam was commissioned on 1 January 1998.

points where the flow with Gibe III exceeds the flow without Gibe III. Such a condition always occurs when the reservoir is at its full capacity. Under such circumstances, flows with Gibe III would be a combination of natural flows (reservoir overflows) and discharge from the Gibe III due to power production and other releases (environmental flows and flood releases). On the other hand, flows without Gibe III would be equal to natural flows only.

\subsection{Approach II: sampling methods}

\subsubsection{Rainfall based scenarios}

The lake level modeling approach was run for the 20 scenarios (Table 2) both with and without the Gibe III dam. Results of this analysis are shown in Fig. 4 and Table 3. The Gibe III dam would reach MOL in 8 months (scenarios 6, 7, 8, 12, and 15 ) to up to 16 months (scenarios 16 and 18) with an average period of 10 months. The time to reach MOL would depend on the amount and distribution of rainfall received after the dam commencement. During the first impoundment period, a below normal rainfall year would prolong this time to more than a year. However, above normal to near normal rainfall year would help the dam to reach MOL in less than a year.
Due to regulated inflows during the first stage of reservoir impoundment, with respect to without the dam, Lake Turkana water levels would drop up to a minimum of $0.8 \mathrm{~m}$ (scenarios 1,16 , and 18) and up to a maximum of $1.6 \mathrm{~m}$ (scenario 6). After the first impoundment period, with respect to without the dam, the lake levels would fluctuate anywhere between 0 to over $4 \mathrm{~m}$ with an average loss up to $1.8 \mathrm{~m}$. The dynamic ranges of fluctuations in each scenario are illustrated in Fig. 4 and Table 3.

Results also indicate that the impact of the dam would be higher in scenarios $6,14,15,18$, and 19 , with over $4 \mathrm{~m}$ drops in lake levels. In all these scenarios, the highest impact occurred only over the years with above normal rainfall. Scenarios 2, 3, 10, 11, and 16 show the least impact, with $<0.5 \mathrm{~m}$ difference with respect to without the dam. These scenarios have more years of below normal rainfall. It is interesting and counterintuitive to see a smaller impact on the lake level when there is below normal rainfall, and a higher impact on the lake level when there is above normal rainfall. This is because, during the dry years, the natural inflows into the lake are reduced. With the dam in place, an average inflow of $550 \mathrm{~m}^{3} \mathrm{~s}^{-1}$ is always guaranteed; hence, the lake levels with the dam will not actually drop as much as they should drop in dry years without the dam. However, 
Table 3. Impact of the Gibe III dam on the Lake Turkana water level assessed using rainfall-based scenarios.

\begin{tabular}{|c|c|c|c|c|c|}
\hline \multirow{3}{*}{$\begin{array}{l}\text { Rainfall } \\
\text { based } \\
\text { scenarios }\end{array}$} & \multirow{3}{*}{$\begin{array}{r}\text { Time to fill Gibe } \\
\text { III reservoir } \\
\text { (reach MOL*) } \\
\text { [Months] }\end{array}$} & \multicolumn{4}{|c|}{ Loss in Lake Turkana levels with respect to no-dam } \\
\hline & & \multirow{2}{*}{$\begin{array}{r}\text { During first } \\
\text { impoundment } \\
{[\mathrm{m}]}\end{array}$} & \multicolumn{3}{|c|}{ After the first impoundment } \\
\hline & & & $\begin{array}{r}\operatorname{Max} \\
{[\mathrm{m}]}\end{array}$ & $\begin{array}{r}\text { Mean } \\
{[\mathrm{m}]}\end{array}$ & $\begin{array}{r}\text { Min } \\
{[\mathrm{m}]}\end{array}$ \\
\hline 1 & 10 & 0.8 & 2.9 & 1.6 & 0.7 \\
\hline 2 & 10 & 1.0 & 2.9 & 1.3 & 0.4 \\
\hline 3 & 9 & 1.1 & 2.6 & 1.0 & 0.0 \\
\hline 4 & 10 & 1.0 & 2.9 & 1.7 & 0.7 \\
\hline 5 & 9 & 1.2 & 2.6 & 1.6 & 0.6 \\
\hline 6 & 8 & 1.6 & 4.0 & 2.4 & 1.3 \\
\hline 7 & 8 & 1.1 & 3.0 & 1.7 & 0.5 \\
\hline 8 & 8 & 1.1 & 3.4 & 2.1 & 1.0 \\
\hline 9 & 9 & 1.2 & 3.5 & 2.1 & 0.8 \\
\hline 10 & 10 & 1.1 & 2.2 & 1.1 & 0.3 \\
\hline 11 & 10 & 1.1 & 3.0 & 1.2 & 0.4 \\
\hline 12 & 8 & 1.1 & 3.8 & 2.5 & 1.0 \\
\hline 13 & 10 & 1.1 & 3.1 & 1.4 & 0.4 \\
\hline 14 & 15 & 0.9 & 4.2 & 1.9 & 0.6 \\
\hline 15 & 8 & 1.6 & 4.3 & 2.2 & 1.0 \\
\hline 16 & 16 & 0.8 & 2.4 & 1.1 & 0.3 \\
\hline 17 & 10 & 1.4 & 3.3 & 1.9 & 0.7 \\
\hline 18 & 16 & 0.8 & 4.0 & 2.4 & 0.7 \\
\hline 19 & 10 & 1.0 & 4.1 & 2.3 & 0.6 \\
\hline 20 & 15 & 0.9 & 2.8 & 1.7 & 0.8 \\
\hline Average & 10 & 1.1 & 3.2 & 1.8 & 0.6 \\
\hline
\end{tabular}

this requires the initial condition that the dam reservoir is above MOL. On the other hand, during the wet years, the lake would always receive moderated inflows, which would be much less than the natural inflows (without the dam) and hence the relative impact on the lake would be higher in wet years.

\subsubsection{Statistical approach}

Results from cross-validation are shown in Fig. 5. Lake levels are predicted for each year using data from other years. Combined results provided an $R^{2}$ of 0.76 . We classified all the years into two different groups based on individual $\mathrm{R}^{2}$ values. Certain years, such as 1998, 2001, 2005, 2006, 2007, and 2008, yielded high correlation $\left(R^{2}>0.5\right)$, while others yielded lower correlation $\left(R^{2}<0.5\right)$. The years that deviated from long-term median distribution yielded low correlation, and those years that followed long-term median distribution yielded higher correlation. The results of simulated lake levels using the NBR technique are shown in Fig. 6 and Table 4. Results indicate that the time required for the Gibe III reservoir to reach MOL is about 8 months for the median scenario. However, the upper and lower $95 \%$ confidence interval (UCI and LCI) indicates that the reservoir would reach MOL in 5 and 15 months, respectively. During initial impoundment, the lake would drop up to $1.2 \mathrm{~m}$ depending on rainfall conditions and initial lake level. The loss in lake level at the end of the simulation period (with respect to without the dam) was found to range from 1.5 to $3.1 \mathrm{~m}$ (LCI); 1.1 to $2.9 \mathrm{~m}$ (median), and 1.0 to $2.2 \mathrm{~m}$ (UCI) depending on the initial lake level. Our results also indicate that as the Gibe III dam would moderate the flows into the lake, peak season flows would reduce but with increased base flow. The seasonal fluctuations in lake level will be dampened from $1.5 \mathrm{~m}$ to $<0.5 \mathrm{~m}$ (Fig. 6).

Based on the results obtained, we accept the hypothesis that the relative hydrological impact of the dam with respect to without Gibe III would depend on the initial Lake Turkana water level at the time of commencement of the dam. The relative hydrological impact at different initial lake levels was estimated by identifying the difference between the lake levels derived without the dam and with the dam at the end of simulation period. Our results indicate that the relative hydrological impact is lowest when the initial lake level is low, and it increases as the initial lake level increases (Fig. 7). To explain this, let us assume two cases: (a) the lake is at a lower initial level $(<363 \mathrm{~m})$ and, (b) the lake is at a higher initial level (higher than or equal to $363 \mathrm{~m}$ ). In the former case when the lake is at a lower initial level, the lake would receive unregulated inflows (with average rate of $650 \mathrm{~m}^{3} \mathrm{~s}^{-1}$ ) without 

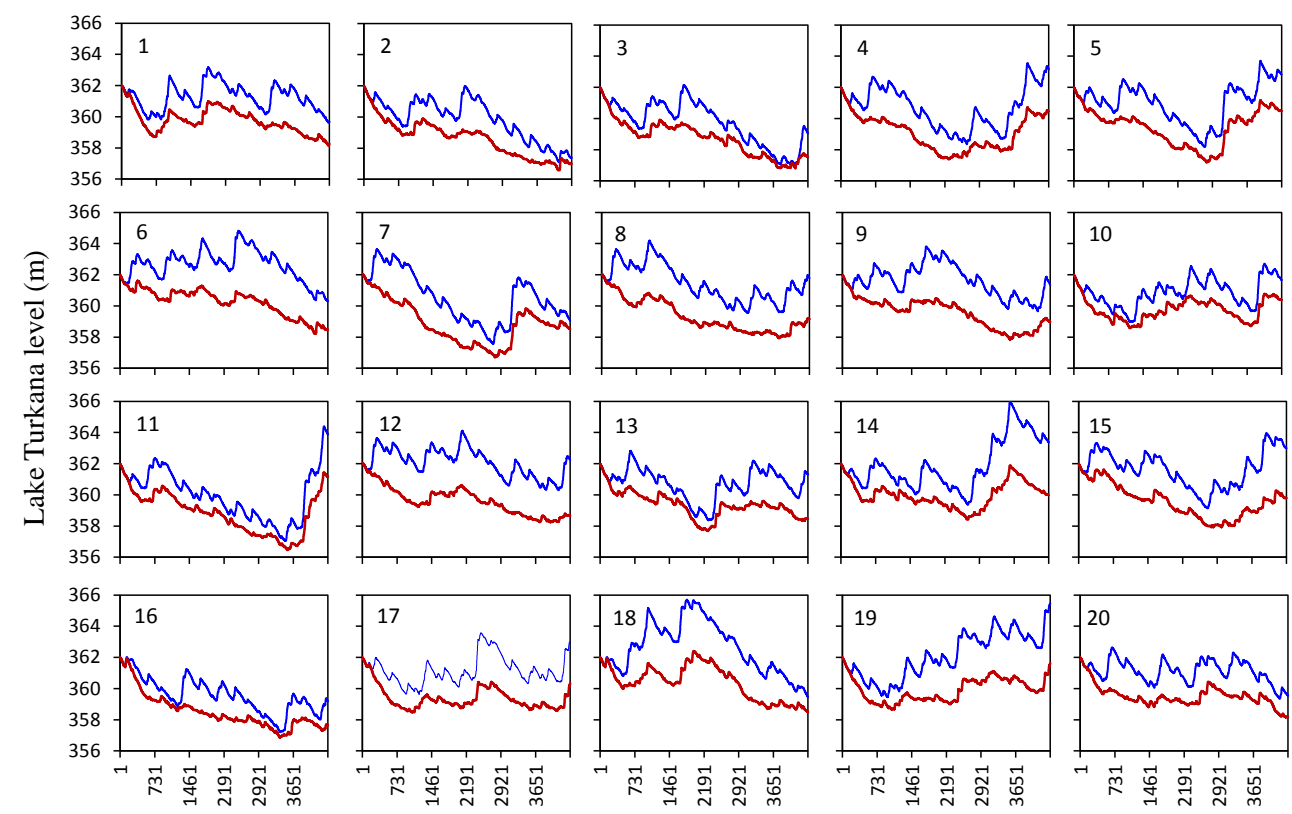

Time (Days after Gibe III commissioning)

Without Gibe III With Gibe III

Fig. 4. Impact of the Gibe III dam on Lake Turkana water levels assessed based on 20 rainfall based rainfall scenarios. The blue line shows the lake level fluctuations under each scenario without the Gibe III dam, and the red line shows the lake level fluctuations after the commissioning of the Gibe III dam.

Gibe III that would not only compensate ET losses but also increase the lake levels. On the other hand, with Gibe III, the lake would receive regulated inflows with an average inflow rate of $550 \mathrm{~m}^{3} \mathrm{~s}^{-1}$. Because of a lower lake level, the volume of regulated inflows $\left(550 \mathrm{~m}^{3} \mathrm{~s}^{-1}\right)$ is more than the ET losses, and the lake levels will increase, but at a smaller rate when compared to without Gibe III (Fig. 6). Hence, the impact (difference between with and without Gibe III) is lower at a lower initial lake level. In the latter case when the lake is at a higher initial level, the lake would receive unregulated inflows (with an average rate of $650 \mathrm{~m}^{3} \mathrm{~s}^{-1}$ ) without Gibe III that would be just enough to compensate the ET losses at a higher initial lake level and hence lake levels would show little change. By contrast, with Gibe III, the lake would receive regulated inflows with an average inflow rate of $550 \mathrm{~m}^{3} \mathrm{~s}^{-1}$. Because of a higher lake level, a larger volume of inflows are required to compensate the total volume of ET losses, and the lake levels will decline rapidly when compared to without Gibe III. Hence, the impact (difference between with and without Gibe III) is higher at a higher initial lake levels. The result from this analysis (Fig. 7) is very important in understanding the interactions between Lake Turkana's initial water level and Gibe III.

\subsection{Comparison of results}

Table 5 presents the comparison of results from all three approaches used in this study to evaluate the impact of the

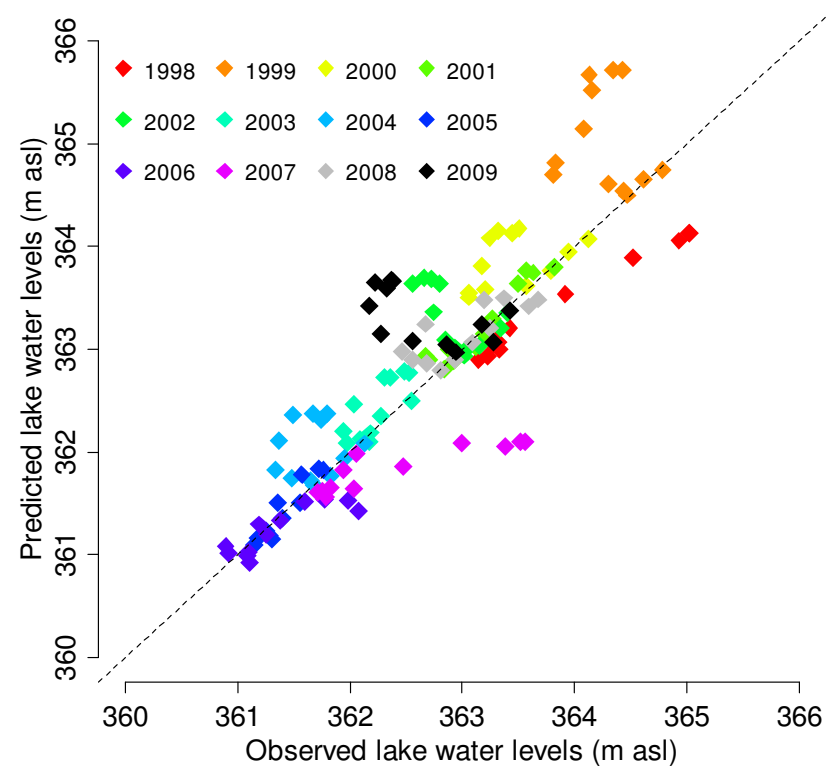

Fig. 5. Cross-validation of lake levels forecasted using nonparametric bootstrap resampling (NBR) technique. Lake levels are predicted for each year using data from other years. For example, lake levels for 2006 are predicted using data from 1998-2005 and 2007-2009. The dotted line is the $1: 1$ line. 
Table 4. Lake level fluctuations modeled using a nonparametric bootstrap resampling (NBR) technique for the period of 12 yr from the commencement of the dam.

\begin{tabular}{|c|c|c|c|c|c|c|c|c|c|}
\hline \multirow{2}{*}{$\begin{array}{l}\text { Initial } \\
\text { Lake } \\
\text { Level } \\
{[\mathrm{m}]}\end{array}$} & \multicolumn{3}{|c|}{$\begin{array}{l}\text { Time to reach MOL } \\
\text { of } 201 \mathrm{~m} \text { [months] }\end{array}$} & \multicolumn{3}{|c|}{$\begin{array}{l}\text { Loss in lake level before } \\
\text { reaching MOL }[\mathrm{m}]\end{array}$} & \multicolumn{3}{|c|}{$\begin{array}{l}\text { Lake level at the end of } \\
12 \mathrm{yr} \text { with respect } \\
\text { to without the dam [m] }\end{array}$} \\
\hline & $\mathrm{UCI}^{\mathrm{b}}$ & $\mathrm{Med}^{\mathrm{b}}$ & $\mathrm{LCI}^{\mathrm{b}}$ & $\mathrm{UCI}^{\mathrm{b}}$ & $\operatorname{Med}^{\mathrm{b}}$ & $\mathrm{LCI}^{\mathrm{b}}$ & $\mathrm{UCI}^{\mathrm{b}}$ & $\operatorname{Med}^{\mathrm{b}}$ & $\mathrm{LCI}^{\mathrm{b}}$ \\
\hline 358 & $<5$ & 8 & 15 & 0.0 & 0.8 & 1.3 & 1.5 & 1.1 & 1.0 \\
\hline 359 & $<5$ & 8 & 15 & 0.0 & 0.9 & 1.4 & 1.6 & 1.2 & 1.0 \\
\hline 360 & $<5$ & 8 & 15 & 0.0 & 0.9 & 1.5 & 1.7 & 1.2 & 1.0 \\
\hline 361 & $<5$ & 8 & 15 & 0.0 & 1.0 & 1.6 & 1.9 & 1.2 & 1.1 \\
\hline 362 & $<5$ & 8 & 15 & 0.0 & 1.0 & 1.7 & 2.2 & 1.5 & 1.1 \\
\hline 363 & $<5$ & 8 & 15 & 0.0 & 1.1 & 1.8 & 2.5 & 2.1 & 1.3 \\
\hline 364 & $<5$ & 8 & 15 & 0.0 & 1.1 & 1.8 & 2.8 & 2.6 & 1.8 \\
\hline 365 & $<5$ & 8 & 15 & 0.0 & 1.2 & 1.9 & 3.1 & 2.9 & 2.2 \\
\hline
\end{tabular}

Note: ${ }^{\mathrm{a}} \mathrm{MOL}=$ minimum operation level; ${ }^{\mathrm{b}} \mathrm{UCI}$ and LCI denote upper and lower bootstrap percentile $95 \%$ confidence intervals respectively and Med represents median value.
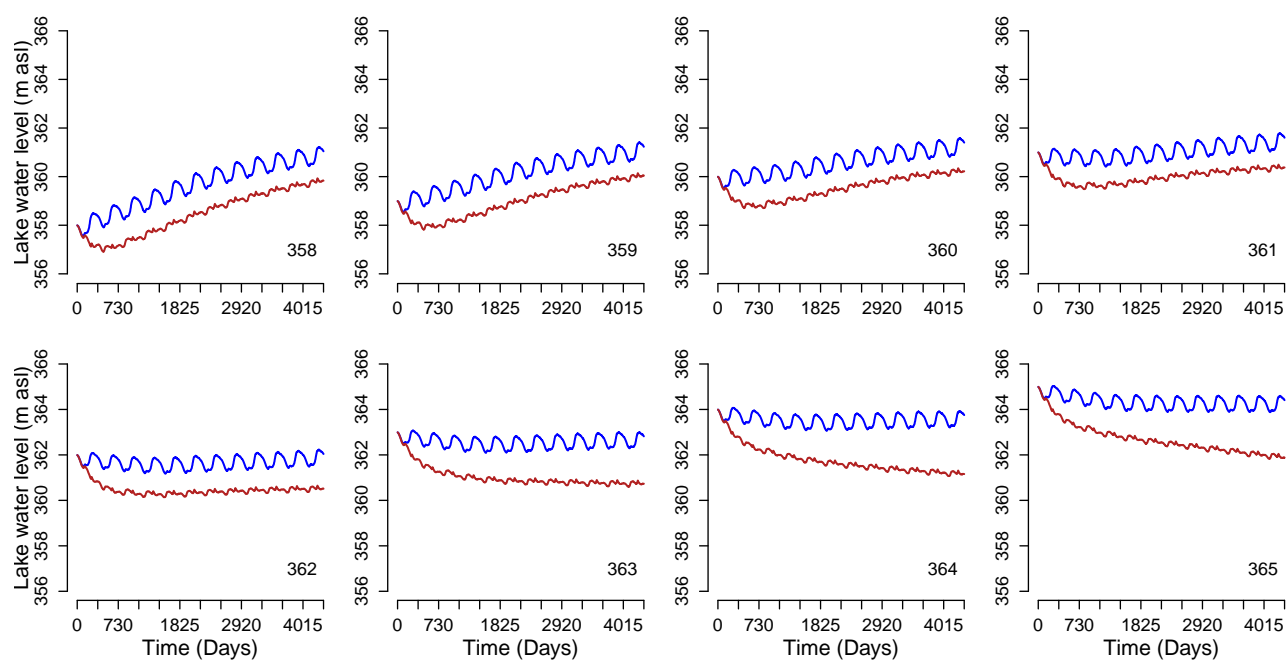

Fig. 6. Impact of the Gibe III dam on the Lake Turkana water levels simulated using the lake level modeling approach and nonparametric bootstrap resampled (NBR) data. The impact of the dam is simulated for different initial lake levels from $358 \mathrm{~m}$ through $365 \mathrm{~m}$ a.s. 1. , shown on the Y-axis. The $\mathrm{X}$-axis shows time (months after the commencement of the dam). The blue line indicates lake level simulated without the dam; the dark red line indicates lake level simulated with the dam.

Table 5. Comparison of results from the three approaches used for the hydrologic assessment of the Gibe III dam.

\begin{tabular}{|c|c|c|c|c|c|}
\hline \multirow[b]{3}{*}{ Approach } & \multirow{3}{*}{$\begin{array}{r}\text { Time to } \\
\text { reach } \\
\text { MOL } \\
\text { [months] }\end{array}$} & \multicolumn{4}{|c|}{$\begin{array}{c}\text { Loss in Lake Turkana water level with } \\
\text { respect to no-dam }\end{array}$} \\
\hline & & \multirow{2}{*}{$\begin{array}{r}\text { During first } \\
\text { impoundment } \\
{[\mathrm{m}]}\end{array}$} & \multicolumn{3}{|c|}{$\begin{array}{l}\text { After the first } \\
\text { impoundment }\end{array}$} \\
\hline & & & $\begin{array}{r}\operatorname{Max} \\
{[\mathrm{m}]}\end{array}$ & $\begin{array}{r}\text { Mean } \\
{[\mathrm{m}]}\end{array}$ & $\begin{array}{r}\text { Min } \\
{[\mathrm{m}]}\end{array}$ \\
\hline Historical approach & 8 & 0.7 & 3.0 & 1.6 & 0.8 \\
\hline Rainfall based approach & 10 & 1.1 & 3.2 & 1.8 & 0.6 \\
\hline Statistical approach & 8 & 1.0 & 3.1 & 1.7 & 1.0 \\
\hline
\end{tabular}

Gibe III dam. The results for the historical approach are directly summarized from Fig. 3a in Table 5. For the rainfall based scenario approach, average results from the 20 different scenarios (see Table 3) are presented, whereas results for the statistical approach are summarized from Table 4 considering outcomes from all the initial lake levels. To reach the MOL level of $201 \mathrm{~m}$, the Gibe III reservoir would take from 8 months (historical approach and statistical approach) to 10 months (rainfall based scenarios). During this period of first impoundment, Lake Turkana would lose anywhere between $0.7 \mathrm{~m}$ (historical approach) and $1.1 \mathrm{~m}$ (rainfall based scenarios). After the first impoundment period, Lake Turkana would lose from a maximum of $3.2 \mathrm{~m}$ to a minimum of $0.6 \mathrm{~m}$, with an average loss of around $1.8 \mathrm{~m}$. Though we present 


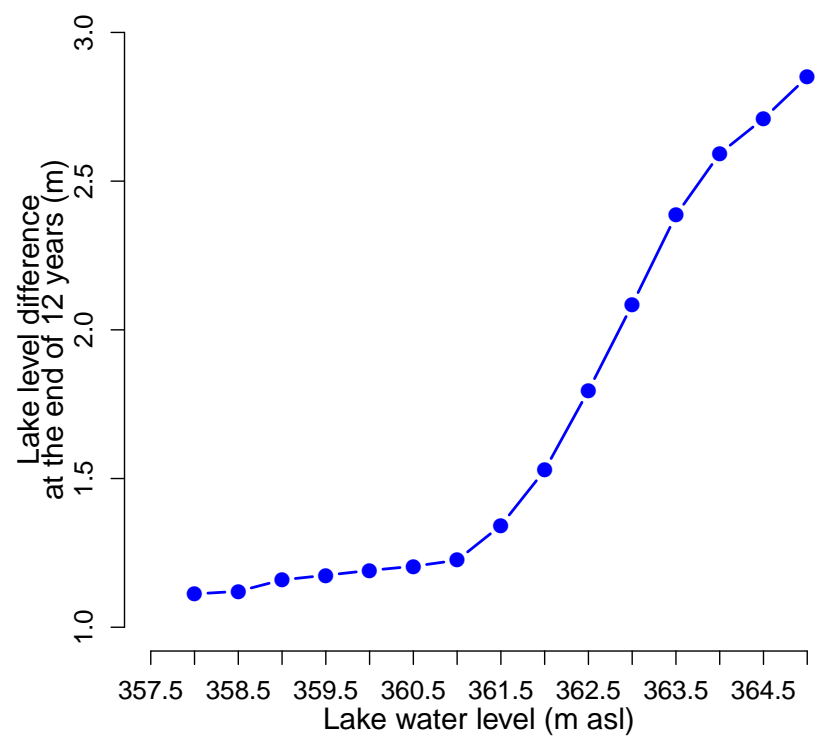

Fig. 7. Impact of the Gibe III dam (difference between with and without dam) at the end of $12 \mathrm{yr}$ simulation period is a function of initial lake level at the time of commencement of the dam.

Table 5 for comparison purposes, it is to be noted that the historical and rainfall based scenarios represent specific future scenarios, and the statistical approach represents a range of plausible future scenarios with different initial lake levels.

\subsection{Analysis of Lake Turkana shoreline changes}

The impact of the Gibe III dam on lake level fluctuations along the shoreline is presented using three possible future scenarios of rainfall (Fig. 8). The dark blue areas (value of 144) in the figure indicate intact regions of the lake that would have water all the time during the modeling period of $12 \mathrm{yr}$. Any color other than dark blue indicates that the lake would have water for fewer months during the modeling period. Figure 8a indicates Gibe III impact under below normal rainfall scenario (lower $95 \%$ confidence interval), where the lake would shrink up to $4 \mathrm{~m}$ from the initial lake level of $362 \mathrm{~m}$. This could cause the lake shoreline to shrink up to $1-2 \mathrm{~km}$ and result in periodic wetting and drying of the shoreline in regions of Omo River delta and Todenyang in the north; Ferguson's Gulf and the Turkwell and Kerio deltas in the west; and South and North Sandy bays, Allia Bay, and Koobi Fora in the west. A total of $22 \%$ of the lake surface area (areas other than dark blue) would show wetting and drying conditions. For the near normal rainfall (median) scenario, the lake would show only small fluctuations (Fig. 8b). With near normal rainfall, the lake would shrink in the Omo River delta, Ferguson's Gulf, the Turkwell and Kerio deltas, and south of Allia Bay, but would soon recover and possibly expand in these regions. Nearly $9 \%$ of the lake surface would show wetting and drying. Finally, in case of an above normal rainfall scenario (upper $95 \%$ confidence interval) due to the Gibe III dam the lake does not show any shrinking
(Fig. 8c). On the other hand, model results indicate that the lake would expand, inundating the Omo River delta, Ferguson's Gulf, the Turkwell and Kerio deltas, Allia Bay, and regions of Koobi Fora. The lake would expand up to $2-3 \mathrm{~km}$ along the shoreline in these areas. A total of $10 \%$ of the area along the lake shoreline would show wetting and drying. Future research should focus on the implications of a decrease or increase in lake level and wetting and drying conditions along the lake shoreline on fisheries, ecology, and hydrology of the lake.

\section{Using multi-source satellite data for Gibe III impact assessment: opportunities and challenges}

\subsection{Uncertainty in data and modeling}

In hydrologic modeling studies, major uncertainties in the model output can be attributed to the model parameters or input data. All the satellite based estimates or modeled data used in this study have some degree of uncertainty. Velpuri et al. (2012) identified that the important variables that influence the uncertainty of Lake Turkana water level estimates are rainfall, modeled runoff and evapotranspiration. Satellite rainfall estimates (RFE) for Africa underestimate up to 30-50\% (Dinku et al., 2008) depending on the location and elevation. In this study, we did not calibrate satellite rainfall directly, as over the lake rainfall contribution to the Lake Turkana water level change was found to be less than $10 \%$. However, while using satellite based rainfall estimates for volumetric studies or where over the lake rainfall contribution is significant, it is critical that rainfall or runoff estimates are calibrated with the in situ observations to minimize the uncertainty. Results for this study indicated that when uncalibrated rainfall data were used to model runoff, the bias in rainfall translated up to $49 \%$ underestimation of lake inflows. Hence, we calibrated modeled runoff data using long term (1964-2001) Omo river flow data obtained from EEPCo (2009). Furthermore, globally available modeled evapotranspiration datasets show uncertainty up to 15$30 \%$ (Mu et al., 2011; Kalma et al., 2008; Senay et al., 2008). This, along with uncertainty in other model parameters, can be translated to uncertainties in the lake level estimates. Hence, we included an error term $\varepsilon$, to account for the data and model errors. The estimate of $\varepsilon$ term $\left(2 \mathrm{~mm} \mathrm{day}^{-1}\right)$ used in this study for Lake Turkana was obtained by Velpuri et al. (2012) by calibrating modeled lake levels using satellite altimetry based Lake Turkana water levels obtained from the French space agency website (Cretaux et al., 2011). More evaluation is needed to understand the individual impacts of the uncertainties in datasets on lake level dynamics. 


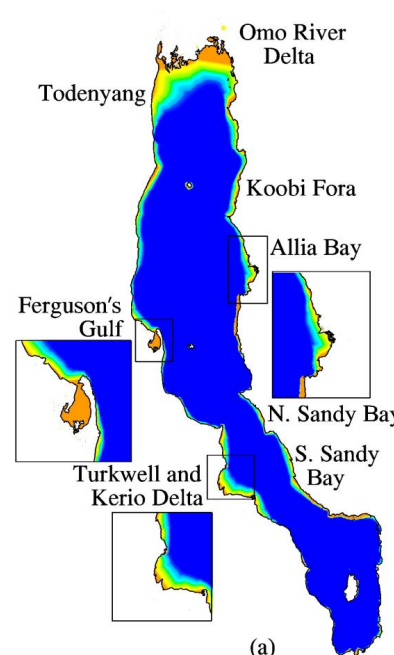

(a)

Initial Lake Level (363 m)

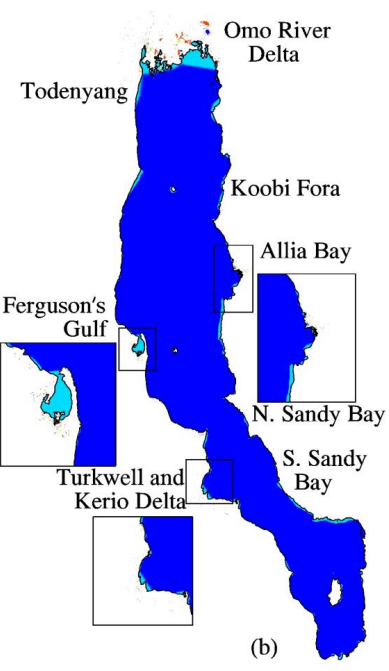

Lake Area under water (in months)

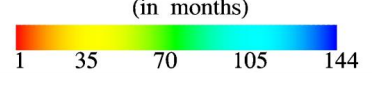

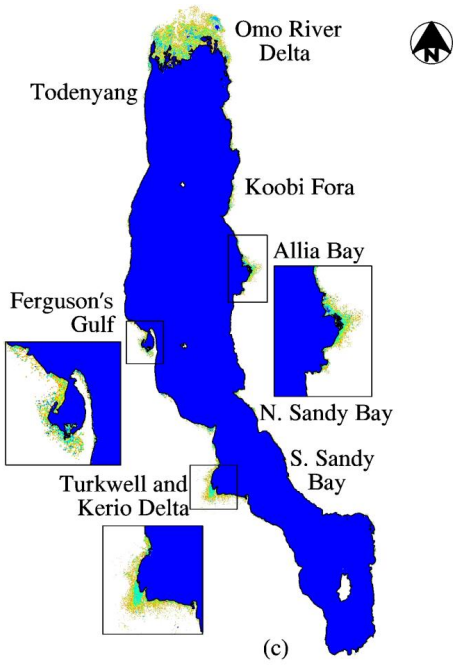

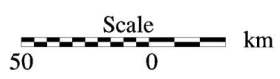

Fig. 8. Simulation of the impact of the Gibe III dam on Lake Turkana shoreline changes under three potential scenarios: (a) below normal rainfall scenario (lower $95 \%$ confidence interval) - the lake shoreline would shrink up to $4 \mathrm{~m}$ inwards from the initial lake level; (b) near normal rainfall scenario (median) - the lake shoreline would not show much variability from the initial lake level; (c) above normal rainfall scenario (upper $95 \%$ confidence interval) - the lake shoreline would grow outwards from the initial lake level, flooding several regions along the shoreline. The color denotes the time in months the lake is under water.

\subsection{Use of existing satellite data for the Gibe III impact assessment}

The main challenge of using remote sensing data for hydrologic predictions is lack of longer time series of data from remote sensing platforms. The global satellite rainfall data is available only since the late 1990s. In this study, we use $12 \mathrm{yr}$ (1998-2009) of satellite-based estimates of rainfall, modeled ET, and runoff data to assess the potential hydrological impact of the Gibe III dam on the Lake Turkana water levels. However, this study is based on the assumption that the rainfall or lake inflows after the commencement of the dam would approximate the long-term distribution (trend and magnitude) of observed historical data (19642001), and rainfall variability observed over the $12 \mathrm{yr}$ period (1998-2009) could represent much of the seasonal and annual rainfall-runoff distribution in the basin. Nevertheless, the actual rainfall may deviate from the observed mean distribution, so the results obtained from this study should be used with caution. In spite of this, we suggest the use of existing satellite data in poorly gauged basins, as they would at least help us understand the possible impacts of the upstream basin developmental activities, such as dams or irrigation on downstream water resources. As more years of satellite and global datasets become available, the method will become more robust and reliable.

\subsection{Use of NBR approach for Gibe III impact assessment}

In this study, we used the simple NBR approach to simulate future scenarios of rainfall, lake inflows, and ET variables. The simulated scenarios of lake inflows and ET may not represent true scenarios as serial dependency is not preserved in the simple NBR approach. On the other hand, since serial correlations are low in daily rainfall, this method could provide reasonable scenarios of rainfall. We also tested nonparametric weighted bootstrap resampling (Lall and Sharma, 1996) and nonparametric block bootstrap resampling (Hardle and Mammen, 2003; Politis, 2003), which would preserve serial dependency in variables. We found that results from these approaches were not very different. The reason for this could be that because we ran the simple NBR a large number of times using the Monte Carlo, and the impact of different combinations of daily runoff including the scenario with serial dependency were possibly captured within the mean and upper and lower $95 \%$ confidence intervals. Thus, this study demonstrates the use of existing data and the NBR approach to reliably simulate future scenarios of climate variables.

\subsection{The use of topo-bathy data for shoreline changes}

In closed-basin lakes such as Lake Turkana, changes in inflows drives changes in the lake level. The Gibe III impact assessment study would be incomplete without understanding the impact of the fluctuating lake level on the lake shoreline. 
The frequency and distribution of the wetting and drying of the Lake Turkana shoreline is highly important for fisheries and ecological studies in the lake. In this study, we used topo-bathy data produced by combining SRTM DEM and bathymetry data to (a) understand the impact of fluctuating lake level on shoreline changes due to the Gibe III dam, (b) identify areas vulnerable to change along the lake shoreline, and (c) identify regions that are prone to periodic wetting and drying along the shoreline as result of lake level fluctuations due to the Gibe III dam. However, the use of topo-bathy data for modeling shoreline changes is based on the assumption that sedimentation in Lake Turkana does not significantly alter the lake shoreline. Furthermore, the application of this method is highly dependent on the availability and accuracy of bathymetry data.

\section{Conclusions}

The main objective of this study was to assess the interactions and potential hydrological impact of the Gibe III dam on Lake Turkana water levels using a calibrated water balance model driven by satellite and model-assimilated global weather data. The impact of the Gibe III dam on the lake water levels is assessed using three different approaches that use existing satellite data and various future scenarios of rainfall, runoff, and evapotranspiration. First, we assessed the impact of the dam using a historical approach assuming that the dam was commissioned in the past. In the second approach, we generated future rainfall scenarios based on the knowledge of the frequency and distribution of droughts and floods in the region. In the third approach, we used the NBR technique to generate different rainfall-runoff scenarios and predict the impact of the Gibe III dam. All the approaches provided comparable and consistent results.

Modeling results indicate that, on average, the reservoir would take up to $8-10$ months to reach the MOL of $201 \mathrm{~m}$. During the initial period of dam/reservoir filling, the lake level would drop up to $1-2 \mathrm{~m}$ (95\% confidence interval). These results are similar to the results published by Avery (2010) and Salini (2010). When compared to the lake level modeled without the dam, the lake levels will decline on average $1.5-2 \mathrm{~m}$ with extremes ranging from less than a meter in lake levels (above normal rainfall scenario) to a little more than $3 \mathrm{~m}$ (below normal rainfall scenario). We also made an interesting finding that the impact of the Gibe III dam would depend on the initial level of Lake Turkana at the time of commencement of the dam, where the relative impact of the dam is larger at higher initial lake levels than lower initial lake levels. The variability of lake levels caused by regulated inflows was found to be within the natural variability of the lake of $4.8 \mathrm{~m}$. In this study, we also identified areas along the Lake Turkana shoreline that are vulnerable to fluctuations in lake levels. Under the near normal rainfall scenario, the lake shoreline would not show much change; however, under the below normal rainfall scenario, the lake's shoreline would shrink $1-2 \mathrm{~km}$, and in the above normal rainfall scenario, the lake shoreline would expand $2-3 \mathrm{~km}$ in some regions. This study demonstrated the use of existing multi-source data for (a) impact assessment of an upstream dam on downstream lakes/reservoirs in regions where in situ data are limited, and (b) analyzing the impact of regulated lake inflows on water level fluctuations and shoreline changes. Results obtained from this study can be used to understand the impact of different operational strategies on the hydrology of the lake. Furthermore, it is important to understand the role of the dam and its impact on Lake Turkana as a hydropower source or as a source of potential irrigation. Because this study focused only on the direct hydrological impact of the Gibe III dam, further study is required to assess (a) the impact of potential diversion of water for irrigation, and (b) the impact of regulated Omo River flows on the ecology and fisheries of Lake Turkana and the lower Omo basin.

Acknowledgements. We thank Ashbindu Singh of the Division of Early Warning and Assessment, United Nations Environment Program for funding field and data collection campaigns to Kenya and Ethiopia. Our thanks also goes to Mehret Debebe and Azeb Asnake of Ethiopian Electric Power Corporation (EEPCo), Ethiopia, for facilitating our field visit to the Gibe III dam site and providing useful technical data for this study. This work was partially supported by Applied Science Program of NASA EarthSun System Division contract \# NNA06CH751. The use of trade, firm, or corporation names in this article is for the information and convenience of the reader. Such use does not constitute an official endorsement or approval by the NASA or USGS of any product or service to the exclusion of others that may be suitable.

Edited by: P. van der Zaag

\section{References}

Asante, K. O.: Approaches to continental scale river flow routing, Ph.D. dissertation, University of Texas at Austin, 281 pp., 2000.

ARWG: A Commentary on the Environmental, Socioeconomic and Human Rights Impacts of the Proposed Gibe III Dam in the Lower Omo River Basin of Southwest Ethiopia, Africa Resources Working Group, available at: http://www.stopgibe3.org/ (last access: 13 September 2012), 2009.

Avery, S. T.: Hydrological impacts of Ethiopia's Omo basin on Kenya's Lake Turkana water levels and Fisheries, The Africa Development Bank, Tunis, 2010.

Behera, S. K., Luo, J. J., Masson, S., Delecluse, P., Gualdi, S., Navarra, A., and Yamagata, T.: Paramount impact of the Indian Ocean dipole on the east African short rains: A CGCM study, J. Climate, 18, 4514-4530, 2005.

Beyene, G. E. and Meissner, B.: Spatio-temporal analyses of correlation between NOAA satelliteRFE and weather stations' rainfall record in Ethiopia, Int. J. Appl. Earth Observ. Geoinf., 12, S69S75, 2010.

Bitew, M. M. and Gebremichael, M.: Evaluation through independent measurements: Complex Terrain and Humid Tropical 
Region in Ethiopia, in: Satellite Rainfall Applications for Surface Hydrology, edited by: Gebremichael, M. and Hossain, F., Springer Publication, Germany, 2009.

Birkett, C. M. and Mason, I. M.: A new global lakes database for a remote sensing program studying climatically sensitive large lakes, J. Great Lakes Res., 21, 307-318, 1995.

Butzer, K. W.: Recent history of an Ethiopian delta - The Omo River and the level of Lake Rudolf, Department of Geography, No. 136, Chicago, USA: University of Chicago Press, 1971.

Camberlin, P., Janicot, S., and Poccard, I.: Seasonality and atmospheric dynamics of the teleconnection between african rainfall and tropical ocean surface temperature: Atlantic vs. ENSO, Int. J. Climatol., 21, 973-1005, 2001.

Carr, C. J.: Patterns of vegetation along the Omo River in the southwest Ethiopia, Plant Ecol., 135, 135-163, 1998.

Cerling, T. E.: A mass-balance approach to basin sedimentation: Constraints on the recent history of the Turkana basin, Palaeogeogr. Palaeocl., 43, 129-151, 1986.

Cheung, W. H., Senay, G. B., and Singh, A.: Trends and spatial distribution of annual and seasonal rainfall in Ethiopia, Int. J. Climatol., 28, 1723-1734, 2008.

Cretaux, J.-F. and Birkett, C.: Lake studies from satellite radar altimetry, C. R. Geosci., 338, 1098-1112, 2006.

Cretaux, J.-F., Jelinski, W., Calmant, S., Kouraev, A., Vuglinski, V., Berge-Nguyen, M., Gennero, M.-C., Nino, F., Abarca Del Rio, R., Cazenave, A., and Maisongrande, P. SOLS: A lake database to monitor in the Near Real Time water level and storage variations from remote sensing data, Adv. Space Res., 47, 1497-1507, 2011.

Dinku, T., Chidzambwa, S., Ceccato, P., Connor, S. J., and Ropelewski, C. F.: Validation of high resolution satellite rainfall products over complex terrain, Int. J. Remote Sens., 29, 40974110, 2008.

Dinku, T., Connor, S. J., and Ceccato, P.: Comparison of CMORPH and TRMM-3B42 over Mountainous Regions of Africa and South America, in: Satellite Rainfall Applications for Surface Hydrology, edited by: Gebremichael, M. and Hossaim, F., Springer Publication, Germany, 193-204, 2010.

EEPCo.: Ethiopian Electric Power Corporation, Gilgel Gibe Hydroelectric power plant Information booklet, An EEPCo Publication, Addis Ababa, Ethiopia, 28 pp., 2004.

EEPCo.: Ethiopian Electric Power Corporation, Gibe III Hydroelectric Project, Reservoir seepage risk analysis, An EEPCo Publication, Addis Ababa, Ethiopia, 82 pp., 2007.

EEPCo.: Gibe III Hydroelectric Project, Environmental \& Social Impact Assessment, CESI \& Mid-Day International, 300 ENVRC002C, An EEPCo Publication, Addis Ababa, Ethiopia, 351 pp., 2009.

Efron, B. and Tibshirani, R. J.: An Introduction to the bootstrap, Chapman Hill, New York, 1993.

FAO.: Digital Soil Map of the World Version 3.5 (CD-ROM), FAO, Rome, 1995.

Farr, T. G. and Kobrick, M.: Shuttle Radar Topography Mission produces a wealth of data, EOS T. Am. Geophys. Un., 81, 583-585, 2000.

Halfman, J. D. and Johnson, T. C.: High resolution record of cyclic climate change during the past 4 ka from Lake Turkana, Kenya, Geology, 16, 496-500, 1988.
Hansen, M. C., Defries, R., Townshend, J., Carrol, M., Dimiceli, C., and Sohlberg, A.: Global percent tree cover at a spatial resolution of 500 meters: first results of the MODIS VCF algorithm, Earth Interact., 7, 1-15, 2003.

Hardle, W. and Mammen, E.: Bootstrap methods for time series, Int. Stat. Rev., 71, 435-460, 2003.

Herman, A., Kumar, V. B., Arkin, P. A., and Kousky, J. V.: Objectively determined 10-day African rainfall estimates created for Famine Early Warning Systems, Int. J. Remote Sens., 18, 2147 2159, 1997.

Hopson, A. J.: Lake Turkana. A report on the findings of the Lake Turkana project 1972-1975, 1-6, Overseas Development Administration, London, UK, 1982.

Kalma, J. D., McVicar, R., and McCabe, F.: Estimating land surface evaporation: A review of methods using remotely sensed surface temperature data, Surv. Geophys., 29, 421-469, 2008.

Kallqvist, T., Lien, L., and Liti, D.: Lake Turkana Limnological Study 1985 - 1988, Research report no. 0-85313, Norwegian Institute of Water Resources, Norway, 98 pp., 1988.

Kolding, J.: A summary of Lake Turkana an ever-changing mixed environment, Mitt. Int. Verein. Limnol., 23, 25-35, 1992.

Lall, U. and Sharma, A.: A nearest neighbor bootstrap for resampling hydrologic time series, Water Resour. Res., 32, 679-693, 1996.

Linsley, R. K., Kohler, M. A., and Paulhus, J. L. H.: Hydrology for engineers, McGraw-Hill, 1975.

Moges, S., Alemu, Y., and Mcfeeters, S.: Flooding in Ethiopia: Recent history and 2006 flood: Implications for the Nile Basin, edited by: Kloos, H. and Legesse, W., Cambria Press, NY, 285305, 2010.

Mu, Q., Zhao, M., and Running, S. W.: Improvements to a MODIS global terrestrial evapotranspiration algorithm, Remote Sens. Environ., 115, 1781-1800, 2011.

Nyamweru, C.: New evidence for the former extent of the Nile drainage system, Geogr. J., 155, 179-188, 1989.

Olivera, F., Flamiglietti, J., and Asante, K.: Global scale flow routing using a source-to-sink algorithm, Water Resour. Res., 36, 2197-2207, 2000.

Politis, D. N.: The impact of bootstrap methods on time series analysis, Stat. Sci., 18, 219-230, 2003.

Rajagopalan, B., Lall, U., Tarboton, D. G., and Bowles, D. S.: Multivariate non-parametric resampling scheme for generation of daily weather variables, Stoch. Hydrol. Hydraul., 11, 65-93, 1997.

Ricketts, R. D. and Johnson, T. C.: Climate change in the Turkana basin as deduced from a 4000 year long $\delta \mathrm{O}^{18}$ record, Earth Planet. Sc. Lett., 142, 7-17, 1996.

Romilly, T. G. and Gebremichael, M.: Evaluation of satellite rainfall estimates over Ethiopian river basins, Hydrol. Earth Syst. Sci., 15, 1505-1514, doi:10.5194/hess-15-1505-2011, 2011.

Salas, J. D., Sveinsson, O. G., Lane, W. L., and Frevert, D. K.: Stochastic streamflow simulation using SAMS-2003, J. Irrig. Drain. E.-ASCE, 132, 112-122, 2006.

Salini: Salini Constructions: Gibe III impact on Turkana lake levels, EEPCo Gibe III Hydroelectric project presentation, Luxembourg, 2010.

Seibert, J. and Beven, K. J.: Gauging the ungauged basin: how many discharge measurements are needed?, Hydrol. Earth Syst. Sci., 13, 883-892, doi:10.5194/hess-13-883-2009, 2009. 
Seleshi, Y. and Zanke, U.: Recent changes in rainfall and rainy days in Ethiopia, Int. J. Climatol., 24, 973-983, 2004.

Senay, G. B.: Modeling landscape evapotranspiration by integrating land surface phenology and water balance algorithm, Algorithms, 1, 52-68, 2008.

Senay, G. B., Verdin, J., Lietzow, R., and Melesse, M.: Global daily reference evapotranspiration modeling and evaluation, J. Am. Water Resour. As., 44, 969-979, 2008.

Senay, G. B., Asante, K., and Artan, G.: Water balance dynamics in the Nile basin, Hydrol. Process., 23, 3675-3681, 2009.

Sivapalan, M.: Prediction in ungauged basins: a grand challenge for theoretical hydrology, Hydrol. Process., 17, 3163-3170, 2003.

Shongwe, M. E., Van Oldenborgh, G.-J., and Van Den Hurk, J. J. M.: Projected Changes in Mean and Extreme Precipitation in Africa under Global Warming, Part I: Southern Africa, J. Climate, 22, 3819-3837, 2009.

Srikanthan, R. and McMahon, T. A.: Stochastic generation of annual, monthly and daily climate data: A review, Hydrol. Earth Syst. Sci., 5, 653-670, doi:10.5194/hess-5-653-2001, 2001.

Tachikawa, T., Kaku, M., Iwasaki, A., Gesch, D., Oimoen, M., Zhang, Z., Danielson, J., Krieger, T., Curtis, B., Haase, J., Abrams, M., Crippen, R., and Carabajal, C.: ASTER Global Digital Elevation Model Version 2 - Summary of validation results, available at: www.jspacesystems.or.jp/ersdac/GDEM/ ver2Validation/Summary_GDEM2_validation_report_final.pdf (last access: 5 October 2012), 2011.
The Gilgel Gibe Affair: An independent study about the Gilgel Gibe hydroelectric projects in Ethiopia - How states and corporations make business using the international public money, Publication of European Union, 2008.

Tucker, C. J., Pinzon, J. E., Brown, M. E., Slayback, D., Pak, E., Mahoney, R., Vermont, E., and Nazmi, E.-S.: An Extended AVHRR 8-km NDVI Data Set Compatible with MODIS and SPOT Vegetation NDVI Data, Int. J. Remote Sens., 14, 44854498, 2005.

Velpuri, N. M., Senay, G. B., and Asante, K. O.: A multi-source satellite data approach for modelling Lake Turkana water level: calibration and validation using satellite altimetry data, Hydrol. Earth Syst. Sci., 16, 1-18, doi:10.5194/hess-16-1-2012, 2012.

Wilks, D. S. and Wilby, R. L.: The weather generation game: A review of stochastic weather models, Prog. Phys. Geog., 23, 329357, 1999.

World Food Program (WFP): Kenya's drought: No sign of any let up, WFP, Rome, Italy, available at: http://reliefweb.int/node/ 70268 (last access: 7 March 2012), 2000.

Xie, P. and Arkin, P. A.: Analysis of Global Monthly Precipitation Using Gauge Observations, Satellite Estimates, and Numeric al Mod el Prediction, J. Climate, 9, 840-858, 1996. 